\title{
Sensitivity of wastewater-based epidemiology for detection of SARS-CoV-2 RNA in a low prevalence setting
}

4 Joanne Hewitt $^{\mathrm{a}^{*}}$, Sam Trowsdale ${ }^{\mathrm{b}}$, Bridget Armstrong ${ }^{\mathrm{c}}$, Joanne R. Chapman ${ }^{\mathrm{a}}$, Kirsten

5 Carter $^{a}$, Dawn Croucher ${ }^{a}$, Cassandra Billiau ${ }^{d}$, Rosemary Sim ${ }^{d}$, Brent J. Gilpin ${ }^{c}$

$7 \quad{ }^{a}$ Institute of Environmental Science and Research Ltd, 34 Kenepuru Drive, Porirua, 5240,

8 New Zealand

$9{ }^{\mathrm{b}}$ School of Environment, University of Auckland, 23 Symonds Street, Auckland, 1010, New

10 Zealand

$11{ }^{\mathrm{c}}$ Institute of Environmental Science and Research Ltd, 27 Creyke Road, Ilam, Christchurch 12 8041, New Zealand

$13{ }^{\mathrm{d}}$ Watercare Services Limited, 52 Aintree Ave, Airport Oaks, Auckland, New Zealand

$16 \quad{ }^{*}$ Corresponding author. Email address joanne.hewitt@esr.cri.nz (Joanne Hewitt)

- Over 4 months, all 0-17 new daily cases in one quarantine building, catchment 120,000 population

- Wastewater tested daily at quarantine building and downstream wastewater treatment plant, WWTP

- SARS-CoV-2 RNA detected in 95.6\% (108/113) at the MIQF and 54.0\% (61/113) at the WWTP

- SARS-CoV-2 RNA detections at the WWTP associated with increasing COVID-19 cases

- Probability of SARS-CoV-2 RNA detection of $87 \%$ with $0.01 \%$ total case prevalence 
medRxiv preprint doi: https://doi.org/10.1101/2021.08.24.21258577; this version posted August 26, 2021. The copyright holder for this preprint (which was not certified by peer review) is the author/funder, who has granted medRxiv a license to display the preprint in perpetuity.

All rights reserved. No reuse allowed without permission.

\section{Abstract}

31 To assist public health responses to COVID-19, wastewater-based epidemiology (WBE) is

32 being utilised internationally to monitor SARS-CoV-2 infections at the community level.

33 However, questions remain regarding the sensitivity of WBE and its use in low prevalence

34 settings. In this study, we estimated the total number of COVID-19 cases required for

35 detection of SARS-CoV-2 RNA in wastewater. To do this, we leveraged a unique situation

36 where, over a 4-month period, all symptomatic and asymptomatic cases, in a population of

37 approximately 120,000 , were precisely known and mainly located in a single managed

38 isolation and quarantine facility (MIQF) building. From 9 July to 6 November 2020, 24-hr

39 composite wastewater samples $(n=113)$ were collected daily from the sewer outside the

40 MIQF, and from the municipal wastewater treatment plant (WWTP) located $5 \mathrm{~km}$

41 downstream. New daily COVID-19 cases at the MIQF ranged from 0 to 17 , and for most of

42 the study period there were no cases outside the MIQF identified. SARS-CoV-2 RNA was

43 detected in $54.0 \%(61 / 113)$ at the WWTP, compared to 95.6\% (108/113) at the MIQF. We

44 used logistic regression to estimate the shedding of SARS-CoV-2 RNA into wastewater

45 based on four infectious shedding models. With a total of 5 and 10 COVID-19 infectious

46 cases per 100,000 population $(0.005 \%$ and $0.01 \%$ prevalence $)$ the predicated probability of

47 SARS-CoV-2 RNA detection at the WWTP was estimated to be 28 and $41 \%$, respectively.

48 When a more realistic proportional shedding model was used, this increased to $58 \%$ and $87 \%$

49 for 5 and 10 cases, respectively. In other words, when 10 individuals were actively shedding

50 SARS-CoV-2 RNA in a catchment of 100,000 individuals, there was a high likelihood of

51 detecting viral RNA in wastewater. SARS-CoV-2 RNA detections at the WWTP were

52 associated with increasing COVID-19 cases. Our results show that WBE provides a reliable

53 and sensitive platform for detecting infections at the community scale, even when case

54 prevalence is low, and can be of use as an early warning system for community outbreaks. 
medRxiv preprint doi: https://doi.org/10.1101/2021.08.24.21258577; this version posted August 26, 2021. The copyright holder for this preprint (which was not certified by peer review) is the author/funder, who has granted medRxiv a license to display the preprint in perpetuity.

All rights reserved. No reuse allowed without permission.

\section{Keywords}

56 Viral shedding, COVID-19, PEG precipitation, RT-qPCR, New Zealand 
medRxiv preprint doi: https://doi.org/10.1101/2021.08.24.21258577; this version posted August 26, 2021. The copyright holder for this preprint (which was not certified by peer review) is the author/funder, who has granted medRxiv a license to display the preprint in perpetuity.

All rights reserved. No reuse allowed without permission.

\section{Graphical Abstract}

58

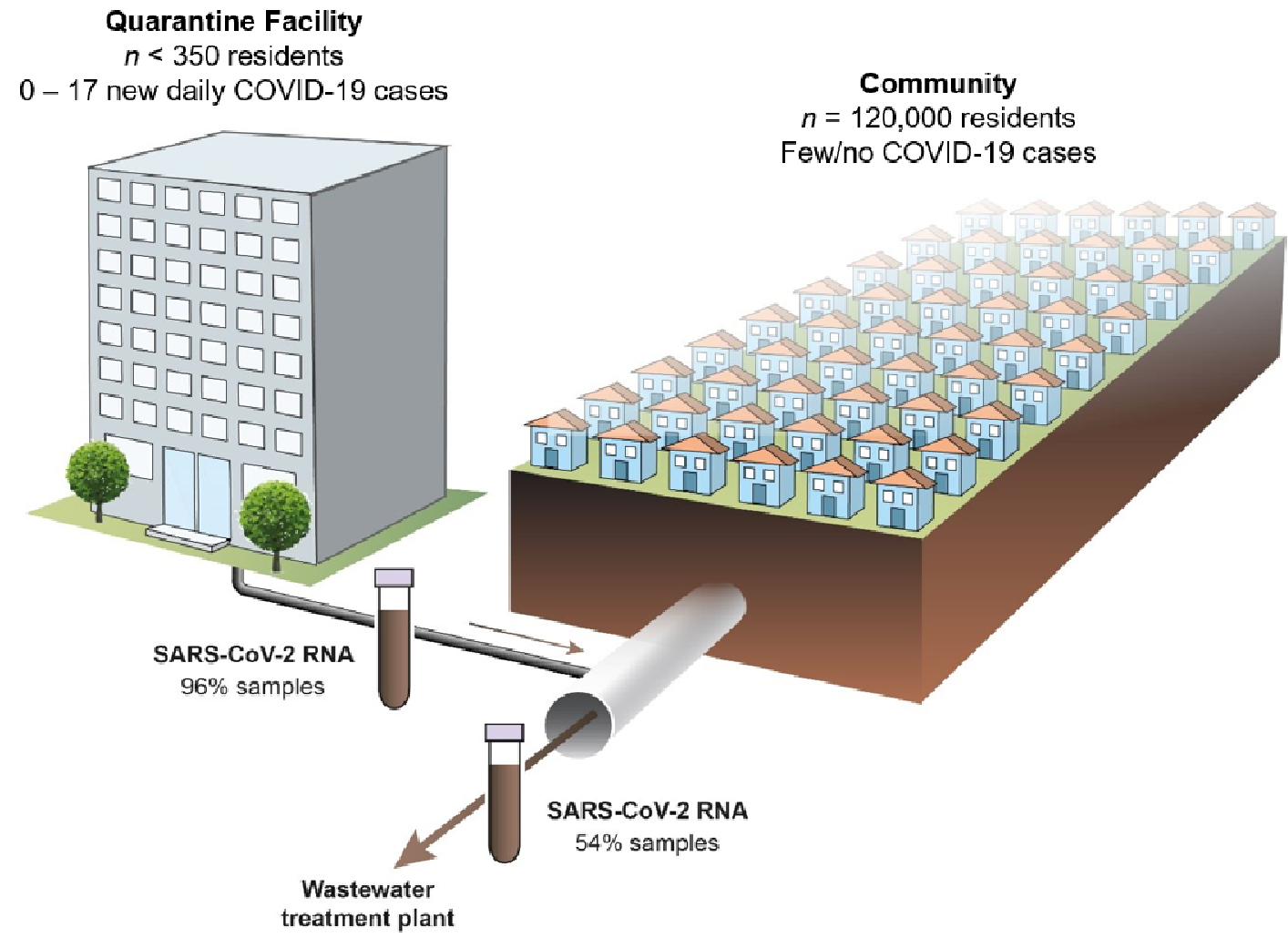

5.9

60

61

62 
medRxiv preprint doi: https://doi.org/10.1101/2021.08.24.21258577; this version posted August 26, 2021. The copyright holder for this preprint (which was not certified by peer review) is the author/funder, who has granted medRxiv a license to display the preprint in perpetuity.

All rights reserved. No reuse allowed without permission.

\section{1. Introduction}

64 Severe acute respiratory syndrome coronavirus 2 (SARS-CoV-2) has rapidly spread around

65 the world since first detected in late 2019 (World Health Organisation 2020). For many

66 countries, the virus has been extremely difficult to control and continues to circulate in the

67 community (AJMC Staff 2021). SARS-CoV-2 RNA is shed into wastewater via faeces and

68 respiratory excretions of symptomatic and asymptomatic individuals (Wölfel et al. 2020,

69 Zhang et al. 2020). This means that wastewater-based epidemiology (WBE) can be used to

70 monitor infections at the community scale (e.g. Lodder and Husman 2020, Peccia et al. 2020,

71 Thompson et al. 2020). WBE complements other COVID-19 surveillance activities (i.e.,

72 diagnostic testing of mainly symptomatic individuals) and can operate at a much broader-

73 scale (Bivins et al. 2020, Sims and Kasprzyk-Hordern 2020). WBE has been coupled with

74 modelling to provide advanced warning (4- to 7-days) of an increase in cases (Peccia et al.

75 2020, Randazzo et al. 2020) and to estimate numbers of asymptomatic and/or undiagnosed

76 cases (Chavarria-Miro et al. 2021, Wu et al. 2020b). WBE has been used at the commercial

77 building or university campus scale to identify unknown cases, and better target public health

78 interventions such as increased screening (Betancourt et al. 2021, Gibas et al. 2021, Harris-

79 Lovett et al. 2021).

80 However, questions remain regarding the sensitivity of wastewater testing to detect infectious

81 COVID-19 cases in communities where there no or limited cases (Cao et al. 2020, Foladori et

82 al. 2020, Medema et al. 2020a, Pecson et al. 2021). It is currently unknown how many cases,

83 per unit of population, are required for SARS-CoV-2 RNA to be reliably detected in

84 municipal wastewater. In locations where the virus is widely circulating, detection in

85 municipal wastewater may be difficult to estimate because undiagnosed or asymptomatic

86 individuals may not be included in case counts. This scenario would result in the sensitivity

87 of detection in wastewater being overestimated. Overestimation would potentially be 
medRxiv preprint doi: https://doi.org/10.1101/2021.08.24.21258577; this version posted August 26, 2021. The copyright holder for this preprint (which was not certified by peer review) is the author/funder, who has granted medRxiv a license to display the preprint in perpetuity.

All rights reserved. No reuse allowed without permission.

88 exacerbated when the number of new cases per day, rather than total cases (i.e., incidence

89 rather than prevalence) is used, given that individuals may continue to shed SARS-CoV-2

90 RNA for weeks following diagnosis (Cevik et al. 2021). While not ideal, daily incidence is

91 the best proxy for total case load in many countries.

92 Aotearoa New Zealand adopted an COVID-19 elimination strategy with the intent of

93 reducing the incidence of cases in the community to zero (e.g., Baker et al. 2020, Jefferies et

94 al. 2020). Since 10 April 2020, all people entering New Zealand have been required to enter a

95 government-run hotel-based managed isolation facility (MIF) upon arrival. All people are

96 tested for COVID-19 on at least days 3 and 12, and if COVID-19 symptoms develop (New

97 Zealand Government 2021). Most individuals who test positive are transferred to a single

98 dedicated managed isolation and quarantine facility (MIQF) in Auckland. In many instances,

99 their close contacts will be transferred at the same time. COVID-19 cases detected in the

100 Auckland community, and their close contacts, are transferred from their home to the MIQF.

101 This MIF system for border arrivals, along with a national lockdown and other measures,

102 meant that by the beginning of June 2020, SARS-CoV-2 transmission was effectively

103 eliminated in New Zealand (Baker et al. 2020). Since then, most New Zealand COVID-19

104 cases have been contained within one (MIQF) building. Interestingly, the MIFQ sits at the

105 end of a wastewater pipe with no sewer upstream. The wastewater from the MIQF drains into

106 a wider sewer pipe network with a resident population catchment of about 120,000. By

107 testing paired daily influent wastewater samples from the sewer outside the MIQF and

108 downstream sewer for the presence of SARS-CoV-2 RNA and comparing results to the

109 known number of symptomatic and asymptomatic COVID-19 cases, we were able to

110 calculate the sensitivity of WBE COVID-19 detection. Four shedding models were used to

111 estimate the contribution of COVID-19 cases to the MIQF and downstream WWTP influent

112 wastewater based on modelled infectious status. 
medRxiv preprint doi: https://doi.org/10.1101/2021.08.24.21258577; this version posted August 26, 2021. The copyright holder for this preprint (which was not certified by peer review) is the author/funder, who has granted medRxiv a license to display the preprint in perpetuity.

All rights reserved. No reuse allowed without permission.

\section{2. Materials and Methods}

\section{$114 \quad 2.1$ Wastewater sampling}

115 Time-weighted composite samples were collected from two sewer sites in the same

116 wastewater catchment. At the MIQF, a temporary sewage maintenance access cover and

117 ISCO autosampler (model 3710, Teledyne ISCO, Lincoln, NE) were installed in the sewer on

1187 July 2020. The sampling point included intermittent pumped flow from two separate

119 wastewater sumps on the premises. The sampler was programmed to collect $60 \mathrm{~mL}$

120 wastewater every $10 \mathrm{~min}$ per $24-\mathrm{hr}$ period into a large plastic drum without refrigeration. The

121 site was visited daily between 12:30 and 13:00 and, after stirring, a $1 \mathrm{~L}$ aliquot of the 24-hr

122 wastewater composite was collected in a plastic bottle and transported on ice to the

123 laboratory. At the inlet to the WWTP, relative to the associated interceptor of the MIQF, an

124 ISCO autosampler (model 4700, Teledyne ISCO) was programmed to collect $200 \mathrm{~mL}$

125 wastewater every $30 \mathrm{~min}$ over $24 \mathrm{hr}$ into a large plastic drum with refrigeration. The site was

126 visited daily between 08:00 and 08:30 and, after stirring, a $1 \mathrm{~L}$ aliquot of the 24-hr

127 composite was collected in a plastic bottle and transported on ice to the laboratory. On arrival

128 at the laboratory, samples were processed within $18 \mathrm{hr}$ of receipt (Sections 2.2 -2.5).

\subsection{Quality controls}

130 Feline infectious peritonitis virus (FIPV), an enveloped coronavirus, and murine norovirus

131 (MNV), a non-enveloped virus, were used as external process controls to monitor virus

132 recovery and to assess any RT-qPCR inhibition. Process control recoveries were not used to

133 adjust the SARS-CoV-2 RNA concentration of the samples (as recommended by Kantor et al.

134 2021).

135 FIPV (ATCC® VR-990 WSU 79-1146) stocks were prepared, and 50\% tissue culture

136 infectious dose $\left(\mathrm{TCID}_{50}\right) / \mathrm{mL}$ determined, in Crandell-Rees Feline Kidney $(\mathrm{CrFK})$ cells 
medRxiv preprint doi: https://doi.org/10.1101/2021.08.24.21258577; this version posted August 26, 2021. The copyright holder for this preprint (which was not certified by peer review) is the author/funder, who has granted medRxiv a license to display the preprint in perpetuity.

All rights reserved. No reuse allowed without permission.

137 (ATCC® CCL-94). MNV stocks were prepared, and plaque forming units (PFU)/mL

138 determined, in RAW 264.7 cells (Hewitt et al. 2009). Working stocks of $10^{6} \mathrm{TCID}_{50} / \mathrm{mL}$

139 FIPV and $10^{6} \mathrm{PFU} / \mathrm{mL}$ MNV were prepared from the initial virus preparations by diluting in

$1402 \%$ Eagle's Minimal Essential Media (Gibco, Waltham, MA). Aliquots were stored at $-80{ }^{\circ} \mathrm{C}$.

141 Prior to virus concentration (Section 2.3), $2 \mu \mathrm{L}$ of FIPV and MNV working stocks were

142 added per $100 \mathrm{~mL}$ wastewater (e.g., $10 \mu \mathrm{L}$ each of FIPV and MNV added to $500 \mathrm{~mL}$ ). For

143 each batch of samples processed, $10 \mu \mathrm{L}$ each of FIPV and MNV working stocks were also

144 added to $2.5 \mathrm{~mL}$ phosphate bu $\square$ ered saline (PBS), $\mathrm{pH} 7.2$ and stored at $4{ }^{\circ} \mathrm{C}$ (for up to $18 \mathrm{hr}$ ).

145 This was referred to as the FIPV/MNV in PBS process control.

146 A SARS-CoV-2 positive extraction quality control was prepared from a clinical specimen

147 submitted for diagnostic testing (ESR, Porirua, NZ). The virus suspension was heat

148 inactivated at $56{ }^{\circ} \mathrm{C}$ for $30 \mathrm{~min}$, diluted $1 / 1000$ in viral transport media, $200 \mu \mathrm{L}$ aliquots

149 prepared and stored at $-80{ }^{\circ} \mathrm{C}$ until required for RNA extraction. The SARS-CoV-2 extraction

150 control was quantified (as described below) and determined as approx. 30,000 genome copies

$151(\mathrm{GC}) / \mathrm{mL}$.

152 2.3 Viral concentration

153 Following seeding of FIPV and MNV into wastewater (Section 2.2), viruses from both liquid

154 and solid fractions were recovered and concentrated using PEG precipitation. Wastewater

155 (500 mL) was centrifuged at $10,000 \mathrm{x}$ g for $20 \mathrm{~min}$ at $4{ }^{\circ} \mathrm{C}$. The supernatant was transferred

156 to a clean bottle and temporarily stored at $4{ }^{\circ} \mathrm{C}$ (maximum $2 \mathrm{hr}$ ). The solids were resuspended

157 in a 1:8 (w/v) ratio of glycine buffer ( $0.05 \mathrm{M}$ glycine, $3 \%$ beef extract), and $\mathrm{pH}$ adjusted to

158 9.0. The bottles were sonicated in an ultrasonic water bath for $2 \mathrm{~min}$, and then placed on a

159 horizontal shaker at $200 \mathrm{rpm}$ for $30 \mathrm{~min}$ at room temperature. Subsequently, the glycine

160 buffer mixture was centrifuged at $10,000 \times \mathrm{g}$ for $20 \mathrm{~min}$ at $4{ }^{\circ} \mathrm{C}$ and the supernatant 
medRxiv preprint doi: https://doi.org/10.1101/2021.08.24.21258577; this version posted August 26, 2021. The copyright holder for this preprint (which was not certified by peer review) is the author/funder, who has granted medRxiv a license to display the preprint in perpetuity.

All rights reserved. No reuse allowed without permission.

161 combined with the initial, chilled, supernatant. The $\mathrm{pH}$ of the entire sample was adjusted to 162 7.0-7.2. Polyethylene glycol 6000 (Sigma-Aldrich, St. Louis, MO) and sodium chloride 163 (Labserv, Auckland, New Zealand) were added to give final concentrations of $20 \%$ and 0.2

164 M, respectively, and gently mixed at room temperature until dissolved. The sample was then 165 placed on a horizontal shaker and gently agitated at $70-80 \mathrm{rpm}$ at $4{ }^{\circ} \mathrm{C}$ for a minimum of $2 \mathrm{~h}$. 166 The sample was centrifuged at $10,000 \mathrm{x}$ g for $30 \mathrm{~min}$ at $4{ }^{\circ} \mathrm{C}$ and supernatant discarded. PBS, $167 \mathrm{pH} 7.2$ was added to resuspend the pellet. The final 'volume before processing' to 'volume 168 after concentration' ratio was approximately 200:1. The final volume was recorded and used 169 in subsequent calculations to determine SARS-CoV-2 RNA GC/L wastewater, and to 170 determine process control recoveries. Wastewater concentrates were stored at $4{ }^{\circ} \mathrm{C}$ 171 (maximum $24 \mathrm{hr}$ ) until viral RNA was extracted.

\section{$172 \quad 2.4$ RNA extraction}

173 The High Pure Viral Nucleic Acid Extraction Kit (Roche Molecular Biochemicals Ltd., 174 Mannheim, Germany) was used to extract viral nucleic acid from a $200 \mu \mathrm{L}$ aliquot of each 175 wastewater concentrate and the FIPV/MNV in PBS process control. One modification was 176 made to the standard protocol; samples were centrifuged at $10,000 \mathrm{x} \mathrm{g}$ for $30 \mathrm{sec}$ prior to 177 addition to the filter. To monitor for RT-qPCR inhibition and/or poor RNA extraction, a 1:4 178 dilution of the concentrate and the FIPV/MNV in PBS process control was also prepared 179 prior to RNA extraction. For each batch of RNA extractions, a positive ( $200 \mu \mathrm{L}$ pre-aliquoted 180 heat inactivated SARS-CoV-2 suspension) and negative (water) extraction control were used.

181 Viral RNA was stored at $4{ }^{\circ} \mathrm{C}$ (maximum $1 \mathrm{hr}$ ) or at $-80{ }^{\circ} \mathrm{C}$ until cDNA synthesis.

$182 \quad 2.5 R T-q P C R$

183 Two-step reverse transcription (RT)-qPCR assays were used for the detection of SARS-CoV-

184 2, FIPV and MNV. Primers and probes are shown in Table S1. For all targets, viral cDNA (5 
medRxiv preprint doi: https://doi.org/10.1101/2021.08.24.21258577; this version posted August 26, 2021. The copyright holder for this preprint (which was not certified by peer review) is the author/funder, who has granted medRxiv a license to display the preprint in perpetuity.

All rights reserved. No reuse allowed without permission.

$185 \mu \mathrm{L}$ ) was first generated from $2.5 \mu \mathrm{L}$ RNA using Superscript ${ }^{\mathrm{TM}}$ III Reverse Transcriptase 186 (Invitrogen) with specific reverse primers (Table S1) according to manufacturer's 187 instructions. RT reactions were carried out at $50{ }^{\circ} \mathrm{C}$ for $30 \mathrm{~min}$ followed by $95{ }^{\circ} \mathrm{C}$ for $4 \mathrm{~min}$. 188 The qPCR consisted of $5 \mu \mathrm{L}$ cDNA, $10 \mu \mathrm{L}$ PerfecTa ToughMix (Quantabio, Beverly, MA), 189 appropriate primers and probe (Biosearch Technologies, Inc., Teddington, UK) and UltraPure 190 DNase/RNase-free distilled water (DNase/RNase-free water, Invitrogen) to a final volume of $19120 \mu \mathrm{L}$. Final primer/probe concentrations were $0.5 \mu \mathrm{M} / 0.25 \mu \mathrm{M}$ (N-gene), $0.6 \mu \mathrm{M} / 0.15 \mu \mathrm{M}$ 192 (FIPV) and $0.4 \mu \mathrm{M} / 0.2 \mu \mathrm{M}(\mathrm{MNV})$. The PCR cycling conditions for all three assays were 95 $193 \square$ for $3 \mathrm{~min}$, followed by 45 cycles of $95 \square$ for 15 secs and $60 \square$ for 30 secs. The N-gene 194 qPCR assay was performed using the CFX96 Touch $^{\mathrm{TM}}$ Real-Time PCR Detection System 195 (Bio-Rad Laboratories, Hercules, CA) and the FIPV and MNV assays performed using CFX 196 Connect $^{\mathrm{TM}}$ (Bio-Rad). All assays were performed in hard shell, clear well, 96-well PCR 197 plates (Bio-Rad), sealed with Microseal B (Bio-Rad). To increase the sensitivity of detection 198 of SARS-CoV-2 RNA, each viral RNA extract from the wastewater concentrates was tested 199 by RT-qPCR in quadruplicate for both extraction volumes (to give a total of eight reactions 200 per sample). FIPV and MNV RT-qPCR assays were performed in duplicate, for both 201 extraction volumes.

202 Controls for the N-gene RT-qPCR assay consisted of SARS-CoV-2 (positive) and 203 DNase/RNase-free water (negative) extraction controls, non-template control (RT and qPCR) 204 and reagent blank (qPCR). In addition, $5 \mu \mathrm{L}$ (total $2 \times 10^{2} \mathrm{GC}$ ) $\mathrm{N}$-gene synthetic DNA 205 oligonucleotide standard (Dnature Diagnostics \& Research Ltd, Gisborne, New Zealand) was 206 included as a positive qPCR control (qPCR only). For FIPV and MNV, a FIPV/MNV in PBS 207 process control (see Section 2.2), RNase/DNase-free water (negative extraction control), non208 template water control (RT and qPCR), and reagent blank (qPCR) were used. 
medRxiv preprint doi: https://doi.org/10.1101/2021.08.24.21258577; this version posted August 26, 2021. The copyright holder for this preprint (which was not certified by peer review) is the author/funder, who has granted medRxiv a license to display the preprint in perpetuity.

All rights reserved. No reuse allowed without permission.

209 PCR cycle quantification threshold $(\mathrm{Cq})$ values were determined in the Bio-Rad CFX 210 Manager ${ }^{\mathrm{TM}}$ Software (Bio-Rad) after correcting for fluorescent drift and manually adjusting

211 to a standardised threshold.

212 Synthetic SARS-CoV-2 RNA Fragment 1 Standard (National Institute of Standards and 213 Technology, Gaithersburg, MD) was used to generate a RNA standard curve and to 214 determine the limit of detection (LOD). RNA standard dilutions of $10^{5}, 10^{4}, 10^{3}, 10^{2}, 50,25$, $21510,5,2$ and $1 \mathrm{GC} /$ reaction were prepared in DNase/RNase free water (Invitrogen) in DNA 216 LoBind tubes (Eppendorf, Hamburg, Germany) to minimise RNA binding. The parameters of 217 the standard curve derived RT-qPCR replicates of $10^{5}$ to 10 GC/reaction were slope, y218 intercept, efficiency and $\mathrm{R}^{2}$ value of $-3.580,37.811,90.3 \%$ and 0.991 respectively.

219 To determine the 95\% LOD (GC/reaction), eight replicates of $10^{3}, 10^{2}, 50$ and 25 $220 \mathrm{GC} /$ reaction, 15 replicates of $10 \mathrm{GC} /$ reaction, and 20 replicates of 5,2 and $1 \mathrm{GC} /$ reaction 221 were analysed. The RNA standard was detected in all replicates down to 10 GC/reaction 222 (mean PCR Cq value $34.8 \pm 0.4$ ), and in $95 \%$ of the $5 \mathrm{GC} /$ reaction replicates (mean PCR Cq 223 value $36.1 \pm 0.9$ ). One and two GC/reaction were detected in approximately 50\% RT-qPCR 224 replicates (mean PCR Cq value $37.2 \pm 0.7$ ). The 95\% LOD was 5 GC/reaction. This equated 225 to $3.4 \log _{10}$ SARS-CoV-2 GC/L (2500 GC/L) wastewater.

226 Results were expressed as positive (SARS-CoV-2 RNA detected) if SARS-CoV-2 RNA was 227 detected in at least one RT-qPCR replicate (with a PCR Cq value $\leq 41$ ), or negative (SARS228 CoV-2 not detected). For the purposes of this study, SARS-CoV-2 RNA quantification was 229 performed for wastewater samples when three or four RT-qPCR replicates were positive and 230 where the mean PCR Cq value $\leq 36.1$ (i.e., equivalent to $5 \mathrm{GC} /$ reaction or greater), with a 231 standard deviation (SD) of the PCR Cq values $\leq 1.0$. For these samples, PCR Cq values were 
medRxiv preprint doi: https://doi.org/10.1101/2021.08.24.21258577; this version posted August 26, 2021. The copyright holder for this preprint (which was not certified by peer review) is the author/funder, who has granted medRxiv a license to display the preprint in perpetuity.

All rights reserved. No reuse allowed without permission.

232 converted to GC/reaction using the standard curve, and then expressed as GC/L wastewater 233 using the formula:

$$
G C / L=\frac{V_{\text {final }(m L)}}{V_{\text {processed }(L)}} * \frac{V_{\text {eluted }(\mu \mathrm{L})}}{\left.\left(V_{\text {extracted }(\mu \mathrm{L})}\right) * V_{P C R}(\mu \mathrm{L})\right)} * 1000 * \mathrm{GC} / \text { reaction }
$$

234 where $V_{\text {final }}$ was the final volume of concentrate $(\mathrm{mL}), \mathrm{V}_{\text {processed }}$ was the initial volume of 235 wastewater processed $(\mathrm{L}), \mathrm{V}_{\text {eluted }}$ was the volume following RNA extraction $(\mu \mathrm{L}), \mathrm{V}_{\text {extracted }}$ 236 was the volume of concentrate extracted $(\mu \mathrm{L})$, and $\mathrm{V}_{\mathrm{PCR}}$ was the volume of RNA used in the 237 RT-qPCR reaction ( $\mu \mathrm{L})$. GC/L was then converted to $\log _{10} \mathrm{GC} / \mathrm{L}$ wastewater.

238 When three or four replicates were positive, but the calculated mean GC/reaction value was $<5$ (i.e., < LOD per reaction), the SARS-CoV-2 RNA quantification (GC/reaction) was

240 imputed as the LOD (i.e., 5) divided by the square root of 2 (Canales et al. 2018). This 241 equated to $3.2 \log _{10} \mathrm{GC} / \mathrm{L}$ wastewater for a concentration factor of 200 . For samples that did 242 not meet either of the above criteria, results were qualitatively presented as presence/absence 243 detection differentiated by either 1 or 2 positive RT-qPCR replicates.

244 FIPV and MNV process control recoveries were calculated using the formula,

$$
\% \text { recovery }=\left(\frac{1}{2^{\Delta \mathrm{Cq}}}\right) * 100
$$

245 where $\Delta \mathrm{Cq}$ was the difference between the mean PCR Cq of the process control recovered in 246 the sample and mean PCR Cq of the FIPV/MNV in PBS process control. Process control 247 recoveries were considered acceptable for quality purposes if both were greater than $1 \%$. By 248 comparing the mean FIPV and MNV PCR Cq values of undiluted and 1:4 diluted samples, 249 any RT-qPCR inhibition could be evaluated by observing a shift in PCR Cq values between 250 the two samples. The 1:4 dilution would theoretically shift the $\mathrm{Cq}$ value by 2 (i.e., a diluted 251 sample gives a higher PCR Cq value when there is no inhibition). 
medRxiv preprint doi: https://doi.org/10.1101/2021.08.24.21258577; this version posted August 26, 2021. The copyright holder for this preprint (which was not certified by peer review) is the author/funder, who has granted medRxiv a license to display the preprint in perpetuity.

All rights reserved. No reuse allowed without permission.

253 Epidemiological data on notified COVID-19 cases (symptomatic or asymptomatic) were 254 obtained from the EpiSurv Surveillance database (https://surv.esr.cri.nz/episurv). These 255 included dates for arrival in the country, transfer to and from the MIQF, onset of illness (if 256 symptomatic), and collection of clinical samples for diagnostic purposes. Based on these 257 data, we used four models to estimate the shedding of SARS-CoV-2 RNA into wastewater 258 based on modelled infectious status:

- Model 1: Total cases - A count of all COVID-19 cases irrespective of their likely infectious status (conservative overestimate).

- Model 2: Infectious cases - A count of likely infectious COVID-19 cases with a

- Model 3: Relative infectious cases - A count of likely infectious COVID-19 cases with a proportional shedding pattern based on He et al. (2020) (Fig. 1), with peak shedding on the day of reported (symptomatic cases) or imputed (asymptomatic cases, see below) disease onset, and proportionately less before and afterwards. Due to the calculation, the relative infectious case number was not restricted to whole numbers.

- Model 4: New daily cases - A count of new cases per day (i.e., daily cases), based on

273 Estimating the degree of infectiousness for individual cases likely provides more realistic 274 estimates of the number of infected people shedding SARS-CoV-2 RNA to wastewater than 275 the total cases in the catchment (Walsh et al. 2020). We assumed that peak shedding for 276 asymptomatic cases occurred on the date that a positive nasopharyngeal swab sample was 
medRxiv preprint doi: https://doi.org/10.1101/2021.08.24.21258577; this version posted August 26, 2021. The copyright holder for this preprint (which was not certified by peer review) is the author/funder, who has granted medRxiv a license to display the preprint in perpetuity.

All rights reserved. No reuse allowed without permission.

277

278

279

280

281

282

283

284

285

286

287

288

289

290

collected. We therefore used this sampling date as a proxy "onset date" and that the shedding

profile was the same as symptomatic cases.

Often, SARS-CoV-2 RNA contributions made by shedding cases would not have been detected until the following day, due to the residence time of wastewater and the nature of the 24-hr sampling scheme. For example, SARS-CoV-2 RNA shed from a MIQF resident at 2pm on Monday would appear in Tuesday's 24-hr composite samples collected at the MIQF and WWTP. The date of wastewater samples therefore reflects the contributions from the previous 24 hours (i.e., date is the day the $24-\mathrm{hr}$ composite sampling ended and collected). Dates relating to occupation and shedding density contribution have been adjusted to reflect the date that wastewater was collected.

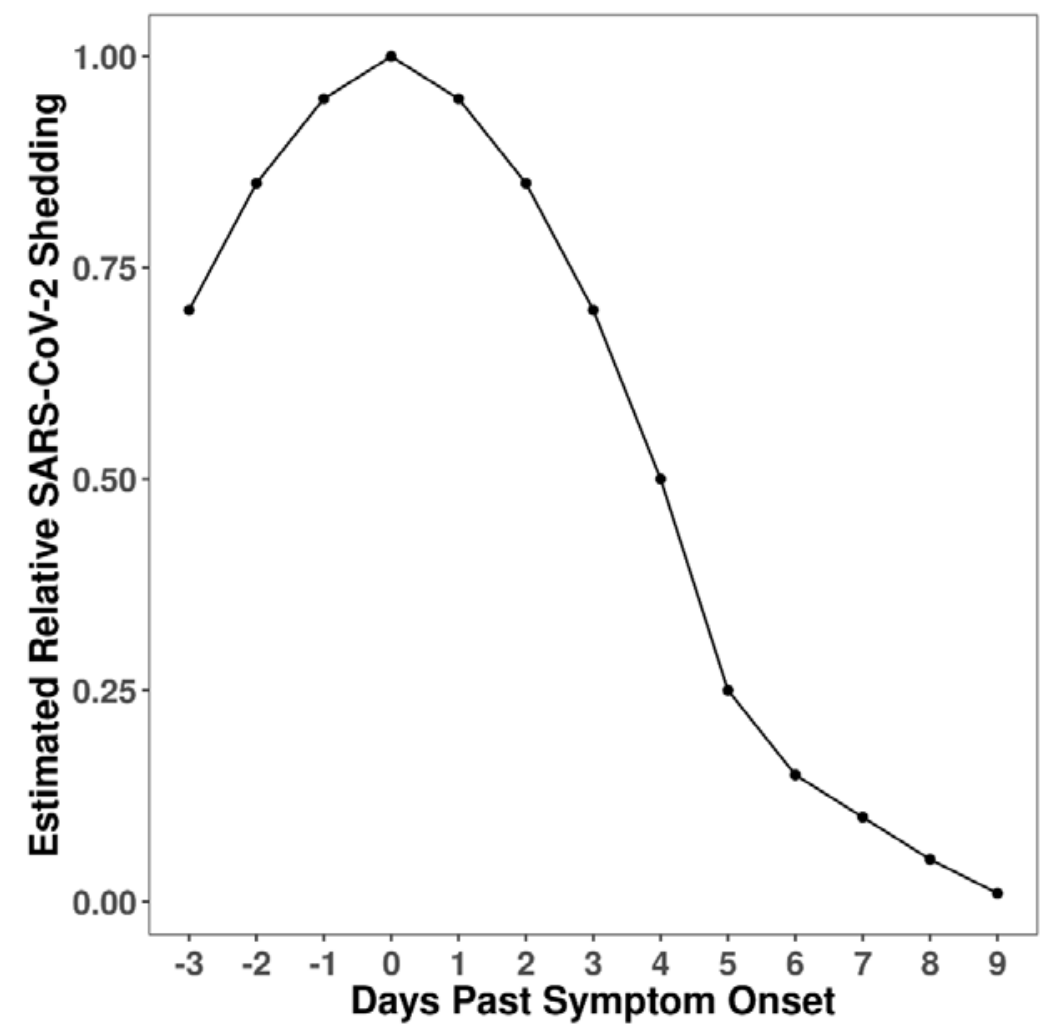

Fig. 1 Model to estimate viral shedding relative to estimated symptom onset date (model 3). Peak shedding at symptom onset date (or estimated onset date), with proportionally less for 3 days prior, and 9 days after, symptom onset date. Model 3 was adapted from He et al. (2020). 
medRxiv preprint doi: https://doi.org/10.1101/2021.08.24.21258577; this version posted August 26, 2021. The copyright holder for this preprint (which was not certified by peer review) is the author/funder, who has granted medRxiv a license to display the preprint in perpetuity.

292

293

294

295

296

297

298

299

300

301

302

303

304

305

306

307

308

309

310

311

312

313

314

315

\subsection{Statistical analysis}

Mean ( \pm bootstrap $95 \%$ confidence intervals $(\mathrm{CI})$ ) process control recovery efficiencies were calculated. Logistic regression was used to model the relationship between the number of COVID-19 cases/case-equivalents putatively shedding at the MIQF, as cases per 100,000 population, and detection of SARS-CoV-2 RNA in the paired MIQF and WWTP wastewater samples. The contributions of asymptomatic and symptomatic COVID-19 cases/caseequivalents putatively shedding at the MIQF (per 100,000 population) were regarded in additive models to examine the relative contribution of asymptomatic cases to WWTP wastewater samples. All statistical analyses were performed in R Statistical Computing Software version 4.0.3 (R Core Team 2020) with Tidyverse (Thompson et al. 2020) used to produce graphs.

\section{Results}

\subsection{Cases in managed isolation and quarantine $(M I Q F)$}

From 9 July to 6 November 2020, there were a total of 335 COVID-19 cases at the MIQF. Of the 335 total cases, 212 were symptomatic and 123 were asymptomatic. Symptomatic cases had an illness onset which ranged from 30 days before arriving at the MIQF to 3 days after arrival, with an average onset of illness 3.3 days before arrival at the MIQF. Overall, COVID-19 cases stayed at the MIQF from 5 - 52 (mean of 13) days (Fig. 2). During the fourmonth study, one cluster of 179 community cases, mostly residing in the WWTP catchment being studied, was reported. All cases were rapidly identified (onset of illness 31 July - 11 September 2020), with 155 cases being transferred to the MIQF between 11 August and 11 September (Fig 2). On 29 August 2020, the total number of cases at the MIQF peaked at 107. This was equivalent to 40 infectious cases (model 2) or 16 relative infectious cases (model 3), and 17 new daily cases (model 4). There were no other known COVID-19 cases outside of 
medRxiv preprint doi: https://doi.org/10.1101/2021.08.24.21258577; this version posted August 26, 2021. The copyright holder for this preprint (which was not certified by peer review) is the author/funder, who has granted medRxiv a license to display the preprint in perpetuity.

All rights reserved. No reuse allowed without permission.

316 the MIQF during this study period. At any one time, there were 5 - 107 total cases (model 1)

317 (equivalent to $4.1-89.2$ cases per 100,000 population), $2.5-50.3$ infectious cases (model 2)

318 or $0.2-15.1$ relative infectious cases (model 3). New daily cases at MIQF (model 4) ranged

319 from a total of $0-17$ (or $0-14.1$ per 100,000 population), with an average of two new cases

320 per day. There were between 41 and 121 (average 93) staff, security, or other non-guests

321 onsite at the MIQF each day (none of them cases), giving a total population at the MIQF each

322 day of about 300-500 individuals who potentially contributed to the wastewater. 


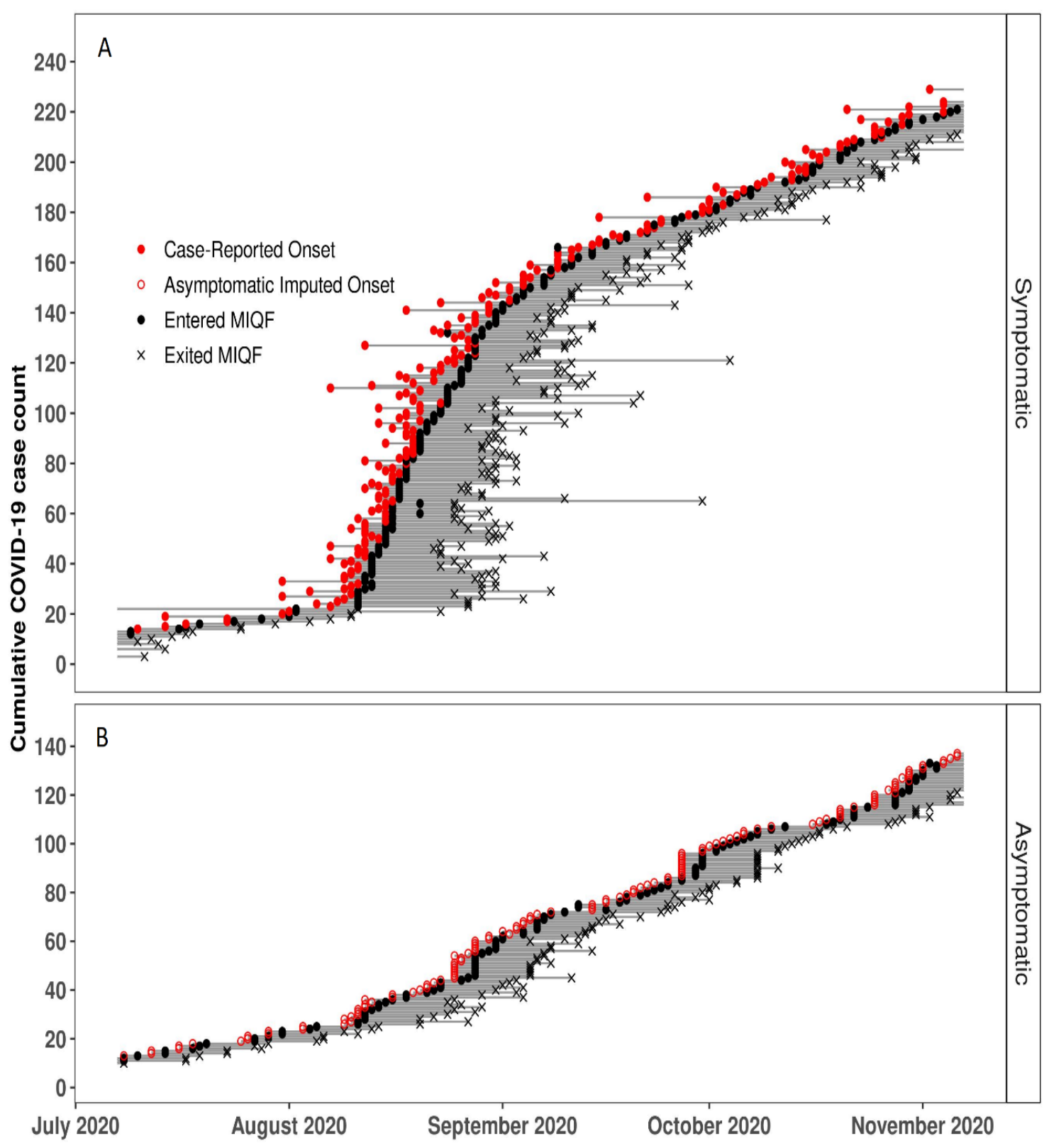

Fig. 2 History of each symptomatic (Panel A) and asymptomatic (Panel B) COVID-19 case at the managed isolation and quarantine facility (MIQF). Closed red circles indicate the date reported as symptom onset, open red circles indicate the imputed symptom onset date for asymptomatic cases. Closed black circles indicate the date the case entered the MIQF. Grey exited the MIQF. 
medRxiv preprint doi: https://doi.org/10.1101/2021.08.24.21258577; this version posted August 26, 2021. The copyright holder for this preprint (which was not certified by peer review) is the author/funder, who has granted medRxiv a license to display the preprint in perpetuity.

All rights reserved. No reuse allowed without permission.

333 Two samples from the MIQF, collected on 19 August and 25 September 2020, had unusual 334 low $\mathrm{pH} /$ visual properties with low FIPV recovery $(0.3 \%$ and $0.5 \%$ respectively). This may

335 have been a result of excess acidic commercial cleaning products being used at the MIQF.

336 Data from the four samples (two MIFQ and two WWTP wastewater) collected on these two 337 dates were excluded from further analyses. Data from the remaining 113 paired samples $(n=$ 338 226) were used for subsequent analyses.

339 Process control recoveries $(\%)$ (mean $\pm 95 \% \mathrm{CI}$ ) from MIQF wastewater samples were $34025.4 \%(22.5,28.5)$ for FIPV and $20.8 \%(18.1,23.8)$ for MNV (Fig. S1a). Recoveries from

341 WWTP wastewater samples were $20.7 \%(16.7,25.1)$ for FIPV and $33.9 \%(30.2,38.2)$ for 342 MNV (Fig. S1a). In samples diluted 1:4 prior to RNA extraction, FIPV and MNV recovery 343 data showed that, overall, there was no significant RT-qPCR inhibition detected in the MIQF 344 or WWTP wastewater samples (Fig. S1b).

\subsection{Detection and quantification of SARS-CoV-2 RNA in wastewater}

346 SARS-CoV-2 RNA was detected in 95.6\% (108/113) of the MIQF wastewater samples.

347 Mean $( \pm$ SD) PCR Cq values for samples ranged from $26.2( \pm 0.1)$ to $37.9( \pm 0.4)$ (Fig. 3a).

348 For the majority $(84.3 \%, 91 / 108)$ of samples where SARS-CoV-2 RNA was detected, all four

349 RT-qPCR replicates were positive. SARS-CoV-2 RNA concentrations in MIQF wastewater 350 ranged from 3.2 to $6.0 \log _{10} \mathrm{GC} / \mathrm{L}$. Non-detection of SARS-CoV-2 RNA in MIQF 351 wastewater occurred on 1 July, 25-27 July, and 3 August 2020.

352 SARS-CoV-2 RNA was detected in 54.0\% (61/113) of the WWTP samples. Of the 61 353 samples where SARS-CoV-2 RNA was detected, 16.4\% (10/61) had four positive RT-qPCR 354 replicates. For these ten samples, mean $( \pm$ SD) PCR Cq values ranged from $33.9( \pm 0.7)$ to $35538.1( \pm 1.2)$ (Fig. 3b), with SARS-CoV-2 RNA concentrations that ranged from 3.3 to 3.8 $356 \log _{10}$ GC/L wastewater from the WWTP influent. For SARS-CoV-2 RNA detections with 1 
medRxiv preprint doi: https://doi.org/10.1101/2021.08.24.21258577; this version posted August 26, 2021. The copyright holder for this preprint (which was not certified by peer review) is the author/funder, who has granted medRxiv a license to display the preprint in perpetuity.

All rights reserved. No reuse allowed without permission.

357

358

359

360

361

362

363

364

365

366

367

368

369

370

371

372

373

374

375

to 3 positive RT-qPCR replicates, the mean $( \pm \mathrm{SD}$ ) PCR Cq value was $37.3 \pm 0.8$ (range 35.6

to 40.4$)$. Notably, over half of the positives $(55.7 \%, 34 / 61)$ had only 1 of 4 positive RT-qPCR

replicates (Fig. 3b).

SARS-CoV-2 RNA was not detected in daily samples from three other Auckland municipal WWTPs, serving a total of ca. 1.2 million population, expect for a few detections (data not shown) in the period of the community cluster in August and early September. This reflects the fact that the area (Auckland) was COVID-19 free during the study and provides confidence that the number of COVID-19 cases was very well quantified by measuring those people in the MIQF. Positive detections in the wastewater therefore were solely due to SARS-CoV-2 RNA input from the MIQF and so the data can be used to quantify detection sensitivity.

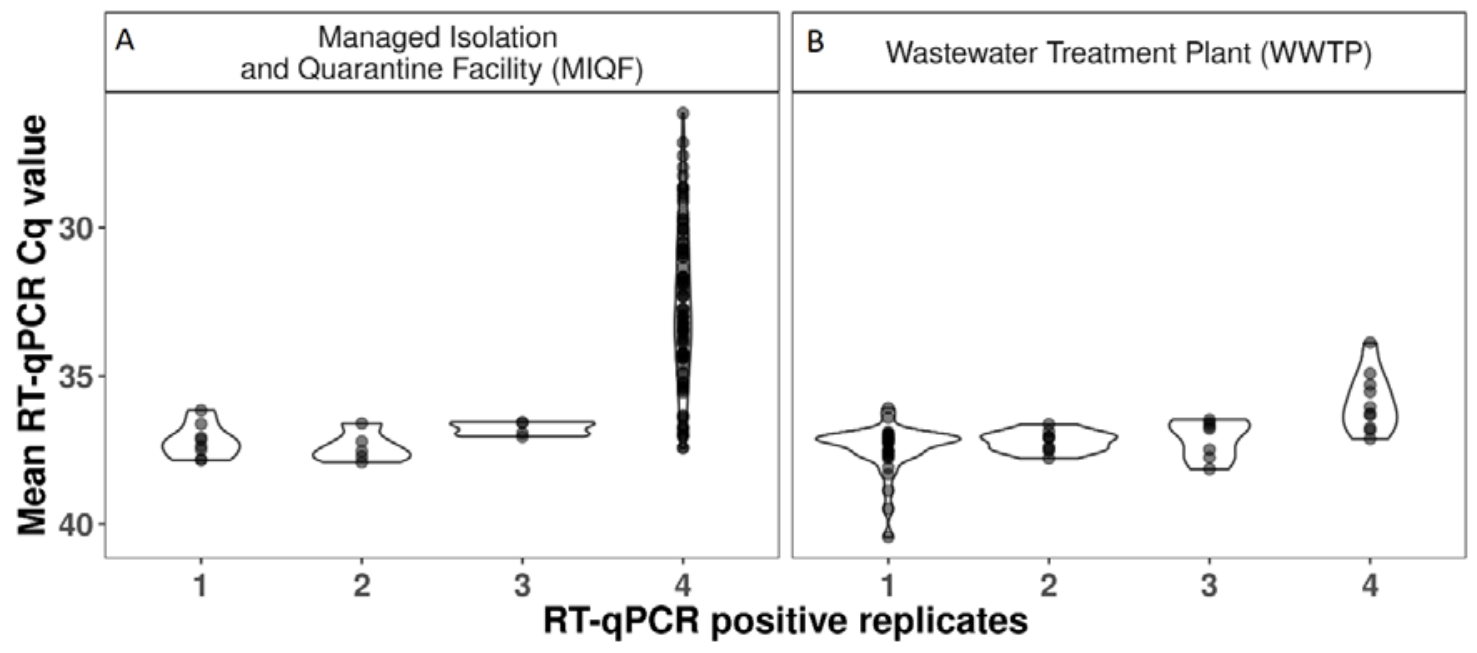

Fig. 3. Number of RT-qPCR replicates positive for SARS-CoV-2 RNA in the MIQF (Panel A) and WWTP wastewater (Panel B) samples. Mean RT-qPCR Cq values are shown with an inverted $\mathrm{y}$-axis (as lower $\mathrm{Cq}$ values represent higher viral concentrations).

\subsection{Relationship between COVID-19 cases and wastewater analysis}

As may be expected, quantifiable SARS-CoV-2 RNA concentrations at the WWTP occurred most often when there were the highest number of individuals potentially shedding SARS- 
medRxiv preprint doi: https://doi.org/10.1101/2021.08.24.21258577; this version posted August 26, 2021. The copyright holder for this preprint (which was not certified by peer review) is the author/funder, who has granted medRxiv a license to display the preprint in perpetuity.

All rights reserved. No reuse allowed without permission.

was modelled on the more restricted shedding assumptions described above.

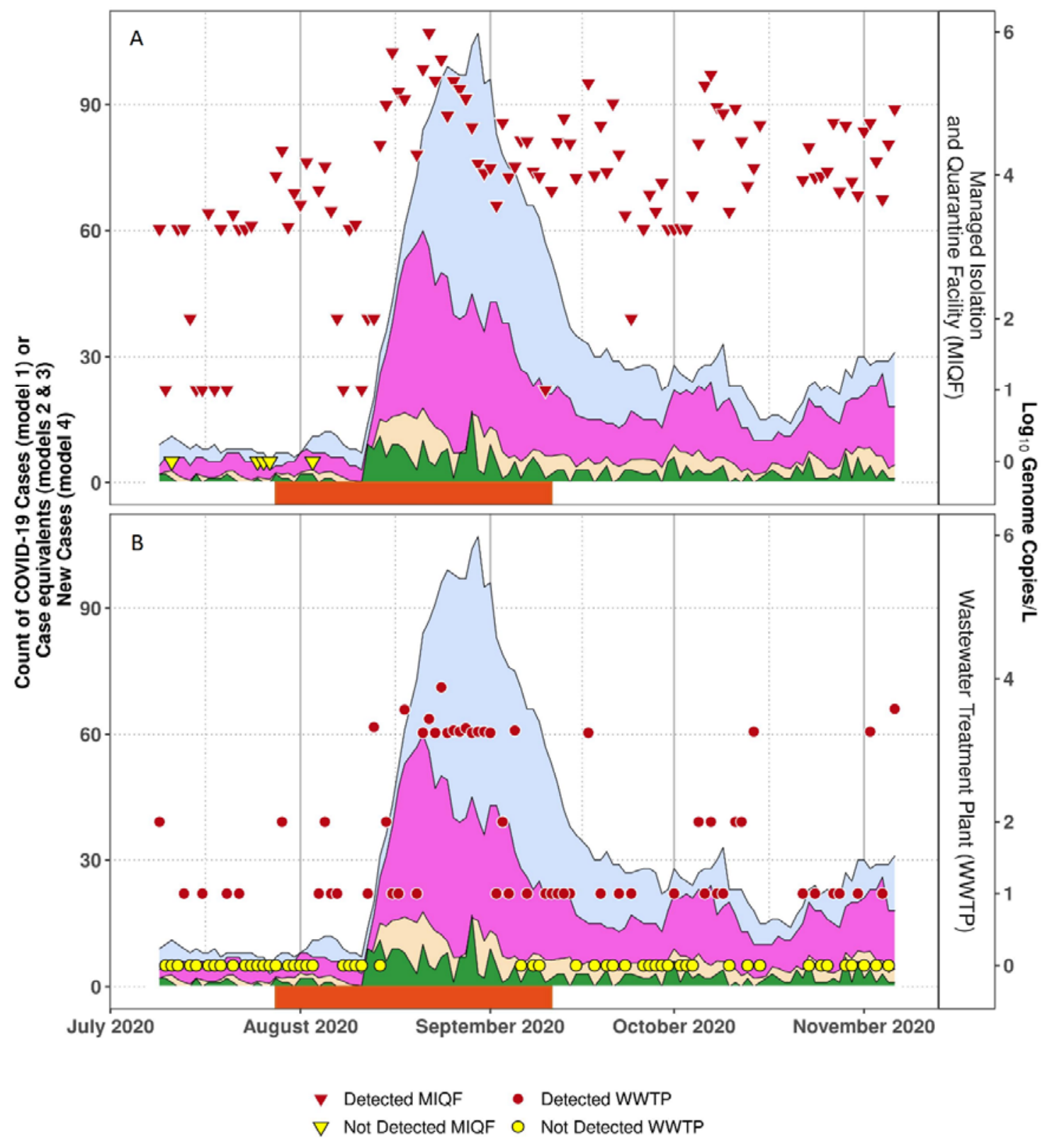

Fig. 4. Detection of SARS-CoV-2 RNA in wastewater collected at the MIQF (Panel A) and at WWTP (Panel B). Red triangles indicate MIQF positive samples, yellow triangles indicate MIQF negative samples, red circles indicate WWTP positive samples, and yellow circles indicate WWTP negative samples. On the y-axis, $\log _{10}$ genome copies/L of 1 or 2 have been imputed to represent the 1 or 2 positive RT-qPCR replicates. Blue shading indicates COVID19 cases at the MIQF on given day (model 1), purple shading estimated infectious cases (model 2), beige shading estimated relative infectious cases (model 3), and green shading new daily cases (model 4 ). The period when community cases were identified ( 28 July to 11 
medRxiv preprint doi: https://doi.org/10.1101/2021.08.24.21258577; this version posted August 26, 2021. The copyright holder for this preprint (which was not certified by peer review) is the author/funder, who has granted medRxiv a license to display the preprint in perpetuity.

All rights reserved. No reuse allowed without permission.

389 When SARS-CoV-2 RNA was detected in the MIQF wastewater $(n=108)$, there were 6 -

390107 total cases (i.e., 5 - 89 per 100,000 population) (model 1). This is equivalent to 3 - 60

391 (i.e., 2.5 - 50 per 100,000 population) infectious cases (model 2) and 0.2 - 9.1(i.e., 0.2 - 7.6

392 per 100,000 population) relative infectious cases (model 3). Non-detections of SARS-CoV-2

393 RNA in the MIQF wastewater were associated with 5 - 11 total MIQF cases (i.e., 4 - 9 per

394 100,000 population) compared to at least 6 total cases when SARS-CoV-2 RNA was

395 detected. The MIFQ wastewater samples with SARS-CoV-2 RNA concentrations more than

$3964.0 \log _{10} \mathrm{GC} / \mathrm{L}$ were collected on days when there were more cases (i.e., 7 - 107 cases (i.e.,

$3975.8-89.2$ per 100,000 population), compared to 0 - 60 cases (i.e., 0 - 50 per 100,000

398 population) depending on the shedding assumptions (Table 1).

399 It is clear from the data that detecting SARS-CoV-2 RNA at the WWTP was more likely

400 when there were at least 8 total cases (i.e., using model 1) (Table 2). This threshold reduced

401 to 4 cases using model 2 and one cases using model 3. SARS-CoV-2 RNA detections at the

402 WWTP, particularly those with three or four RT-qPCR replicates, were associated with an

403 increase in the number of total (model 1), infectious (model 2), relative infectious (model 3),

404 or new daily (model 4) cases in the catchment (Table 2). 
Table 1. Estimated COVID-19 case equivalents at the MIQF when SARS-CoV-2 RNA was either not detected, detected at $\leq 4.0$ log 10 GC/L or detected at $>4.0 \log _{10} \mathrm{GC} / \mathrm{L}$ wastewater collected at the MIQF $(n=113)$.

\begin{tabular}{|c|c|c|c|c|c|}
\hline \multirow[b]{2}{*}{$\begin{array}{l}\text { SARS-CoV-2 RNA } \\
\text { in MIQF wastewater }\end{array}$} & \multirow[b]{2}{*}{$\begin{array}{c}\text { No of } \\
\text { samples }\end{array}$} & \multicolumn{4}{|c|}{$\begin{array}{l}\text { Average number of COVID-19 cases } \\
\text { at the MIQF (Minimum - Maximum) }\end{array}$} \\
\hline & & $\begin{array}{l}\text { Total cases } \\
\text { Model } 1\end{array}$ & $\begin{array}{l}\text { Infectious cases } \\
\text { Model } 2\end{array}$ & $\begin{array}{c}\text { Relative } \\
\text { infectious cases } \\
\text { Model } 3\end{array}$ & $\begin{array}{c}\text { New daily cases } \\
\text { Model } 4\end{array}$ \\
\hline Not detected & 5 & $8.2(5-11)$ & $5.2(3-7)$ & $1.7(0.8-3.0)$ & $0.8(0-2)$ \\
\hline Detected $\left(\leq 4.0 \log _{10} \mathrm{GC} / \mathrm{L}\right)$ & 56 & $21.1(6-83)$ & $12.8(3-43)$ & $4.2(0.2-12.2)$ & $1.8(0-9)$ \\
\hline Detected $\left(>4.0 \log _{10} \mathrm{GC} / \mathrm{L}\right)$ & 52 & $49.5(7-107)$ & $27.4(4-60)$ & $8.0(2.0-17.7)$ & $3.9(0-17)$ \\
\hline Total & 113 & $33.6(5-107)$ & $19.2(3-60)$ & $5.8(0.2-17.7)$ & $2.7(0-17)$ \\
\hline
\end{tabular}

Table 2. Estimated COVID-19 case equivalents at the MIQF when SARS-CoV-2 RNA was either not detected, detected in 1 or 2 RT-qPCR replicates, or detected in 3 or 4 RT-qPCR replicates at the WWTP $(n=113)$.

Average number of COVID-19 cases at the MIQF (Minimum - Maximum)

\section{SARS-CoV-2 RNA} in WWTP wastewater

Not detected

Detected: 1 or 2 replicates

Detected: 3 or 4 replicates

\begin{tabular}{ccccc} 
& \multicolumn{4}{c}{$\begin{array}{c}\text { Average number of COVID-19 cases } \\
\text { at the MIQF (Minimum - Maximum) }\end{array}$} \\
\cline { 2 - 5 } $\begin{array}{l}\text { No of } \\
\text { Samples }\end{array}$ & $\begin{array}{c}\text { Total cases } \\
\text { Model 1 }\end{array}$ & $\begin{array}{c}\text { Infectious cases } \\
\text { Model 2 }\end{array}$ & $\begin{array}{c}\text { Relative } \\
\text { infectious cases } \\
\text { Model 3 }\end{array}$ & $\begin{array}{c}\text { New daily cases } \\
\text { Model 4 }\end{array}$ \\
\hline 52 & $20.1(5-71)$ & $12.6(3-28)$ & $4.0(0.2-15.0)$ & $1.8(0-11)$ \\
42 & $32.1(8-83)$ & $19.6(4-57)$ & $6.0(1.0-15.9)$ & $2.5(0-9)$ \\
19 & $75.0(18-107)$ & $37.2(10-60)$ & $10.3(2.0-17.7)$ & $5.7(0-17)$ \\
\hline
\end{tabular}


medRxiv preprint doi: https://doi.org/10.1101/2021.08.24.21258577; this version posted August 26, 2021. The copyright holder for this preprint (which was not certified by peer review) is the author/funder, who has granted medRxiv a license to display the preprint in perpetuity.

All rights reserved. No reuse allowed without permission.

414 Logistic regression models were fitted to data excluding and including the period of the 415 community COVID-19 cluster for each shedding model (Fig. 5). When the data during the

416 community cluster were excluded, increases in relative infectious cases and new daily cases,

417 was not significantly associated with SARS-CoV-2 RNA detection at the WWTP $(\mathrm{df}=67$,

418 model 3: $\mathrm{p}=0.113$; model 4: $\mathrm{p}=0.372$ ). Case load and infectious cases were significantly

419 associated with an increase in SARS-CoV-2 RNA detection at the WWTP $(\mathrm{df}=67$, model 1:

$420 \mathrm{p}=0.012$, model 2: $\mathrm{p}=0.033)($ Table $\mathrm{S} 2)$.

421 However, when the community cluster data was included, increasing cases for all models

422 were associated with an increased probability of detection at the WWTP $(\mathrm{df}=112$, models 1 ,

4232 \& 3: $\mathrm{p}<0.001$, model 4: $\mathrm{p}=0.003)$ (Table S2).
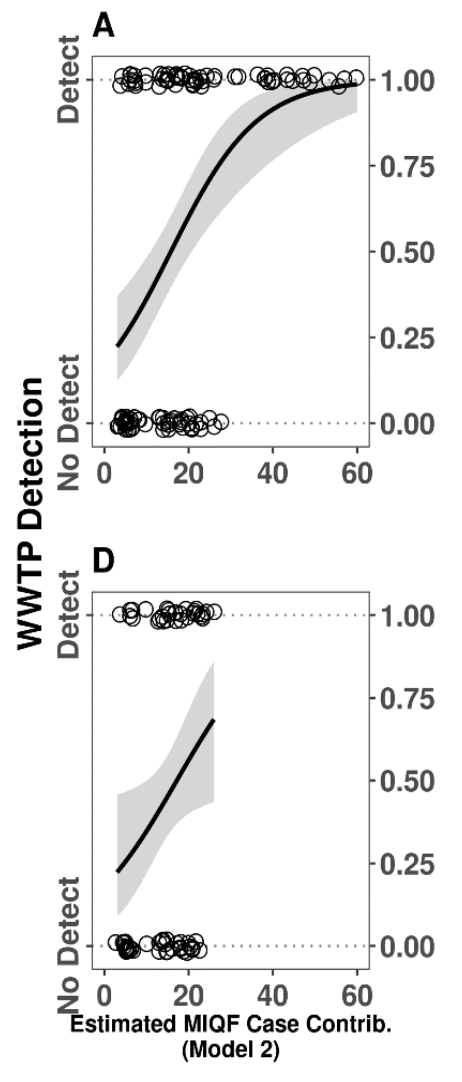

425

426

427

428
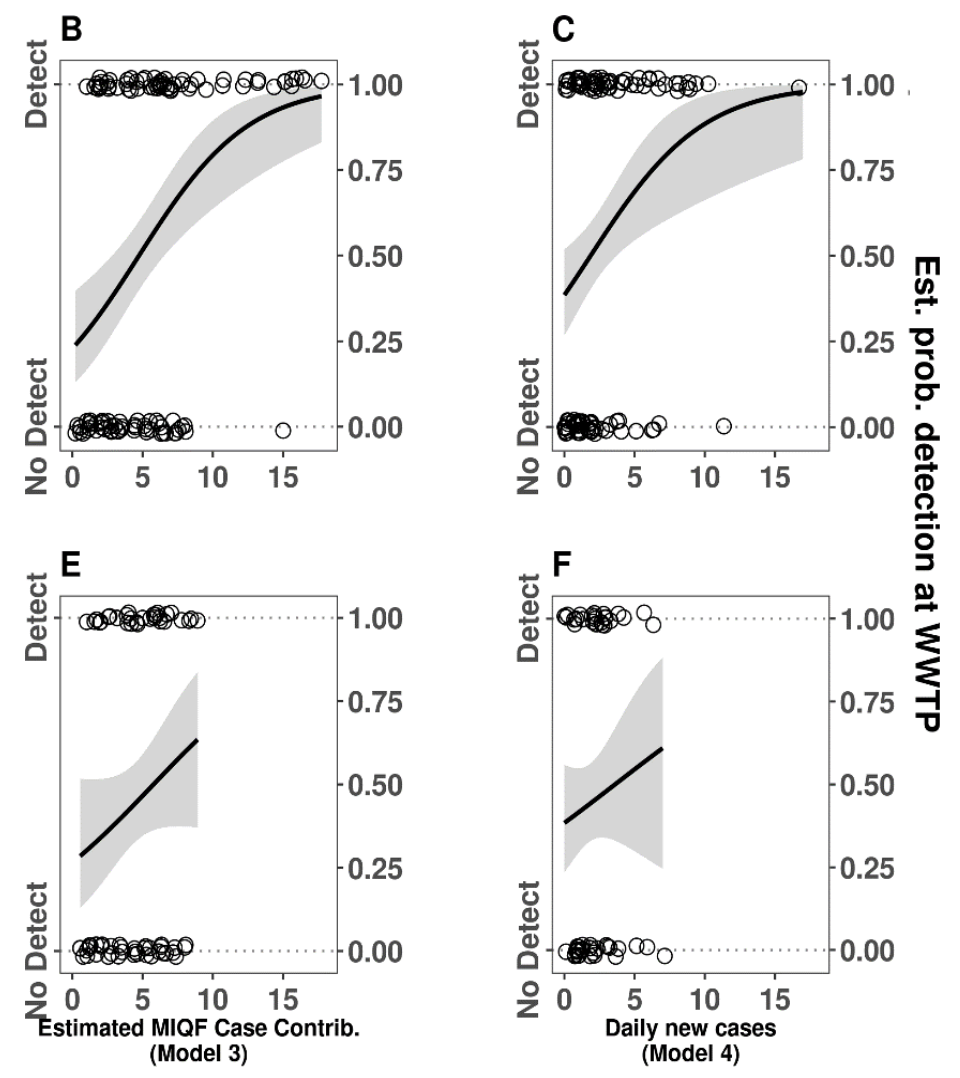

Fig. 5. Logistic regression of the probability of detecting SARS-CoV-2 RNA at the WWTP, estimated using A) MIQF infectious cases (model 2) for the whole study period; B) MIQF relative infectious cases (model 3) for the whole study period; C) New daily cases (model 4) for the whole study period; D) MIQF infectious cases (model 2) excluding the community 
medRxiv preprint doi: https://doi.org/10.1101/2021.08.24.21258577; this version posted August 26, 2021. The copyright holder for this preprint (which was not certified by peer review) is the author/funder, who has granted medRxiv a license to display the preprint in perpetuity.

All rights reserved. No reuse allowed without permission.

cluster data; E) MIQF relative infectious cases (model 3) excluding the community cluster

Table 3: Predicted probabilities of SARS-CoV-2 RNA detection at the WWTP by selected equivalent case counts (per 100,000 population) from logistic regression models fitted with community cluster data.

\section{Expected probability of positive tests in WWTP wastewater (95\% Confidence interval)}

\begin{tabular}{ccccc}
$\begin{array}{c}\text { COVID-19 } \\
\text { case count } \\
\text { per 100,000 } \\
\text { (prevalence) }\end{array}$ & $\begin{array}{c}\text { Total } \\
\text { cases } \\
(\text { model 1) }\end{array}$ & $\begin{array}{c}\text { Infectious } \\
\text { cases } \\
\text { (model 2) }\end{array}$ & $\begin{array}{c}\text { Relative } \\
\text { infectious cases } \\
\text { (model 3) }\end{array}$ & $\begin{array}{c}\text { New daily } \\
\text { cases } \\
\text { (model 4) }\end{array}$ \\
\hline $1(0.001 \%)$ & $24 \%(13-38)$ & $19 \%(10-34)$ & $29 \%(18-43)$ & $46 \%(36-56)$ \\
$5(0.005 \%)$ & $28 \%(17-42)$ & $28 \%(17-41)$ & $58 \%(47-68)$ & $74 \%(57-86)$ \\
$10(0.01 \%)$ & $34 \%(23-46)$ & $41 \%(30-52)$ & $87 \%(70-95)$ & $93 \%(70-99)$ \\
$20(0.02 \%)$ & $47 \%(37-58)$ & $69 \%(56-80)$ & $99 \%(92-100) *$ & - \\
$40(0.04 \%)$ & $74 \%(59-85)$ & $96 \%(83-99)$ & $100 \%(99-100) *$ & - \\
\hline & & & $*$ Extrapolation beyond available data
\end{tabular}

436 The proportion of symptomatic to asymptomatic cases at the MIQF varied with SARS-CoV-2

437 RNA detections at the WWTP (Fig. 6). The interquartile range (IQR) of ratios was higher in

438 the 19 WWTP samples with three or four positive RT-qPCR replicates (IQR $=2.5-5.8$

439 symptomatic cases to every asymptomatic case) than for the 42 WWTP samples with only

440 one or two positive RT-qPCR replicates (IQR $=0.78-2.4$ symptomatic cases to every

441 asymptomatic case) and for the 52 WWTP samples where SARS-CoV-2 RNA was not

442 detected (IQR $=0.71-1.8$ symptomatic cases to every asymptomatic case).

443 Logistic regression models with terms for symptomatic and asymptomatic case contributions

444 for infectious cases (model 2) and relative infectious cases (model 3), and new daily cases

445 (model 4) were significantly associated with an increase in probability of detection of SARS-

446 CoV-2 RNA at the WWTP for symptomatic cases $(\mathrm{df}=112$, model $2 \& 3: \mathrm{p}=0.002$, model

447 4: $\mathrm{p}=0.008$ ) (Supp. Table S2). However, asymptomatic cases were not significantly

448 associated with an increase in probability of detection of SARS-CoV-2 RNA at the WWTP

449 for any shedding model $(\mathrm{df}=112$, model $2: \mathrm{p}=0.488$, model $3: \mathrm{p}=0.661$, model $4: \mathrm{p}=$ 
medRxiv preprint doi: https://doi.org/10.1101/2021.08.24.21258577; this version posted August 26, 2021. The copyright holder for this preprint (which was not certified by peer review) is the author/funder, who has granted medRxiv a license to display the preprint in perpetuity.

All rights reserved. No reuse allowed without permission.

450 0.461) (Supp. Table S2). This indicates that asymptomatic cases are likely to be shedding less

451 detectable SARS-CoV-2 RNA into wastewater.

452

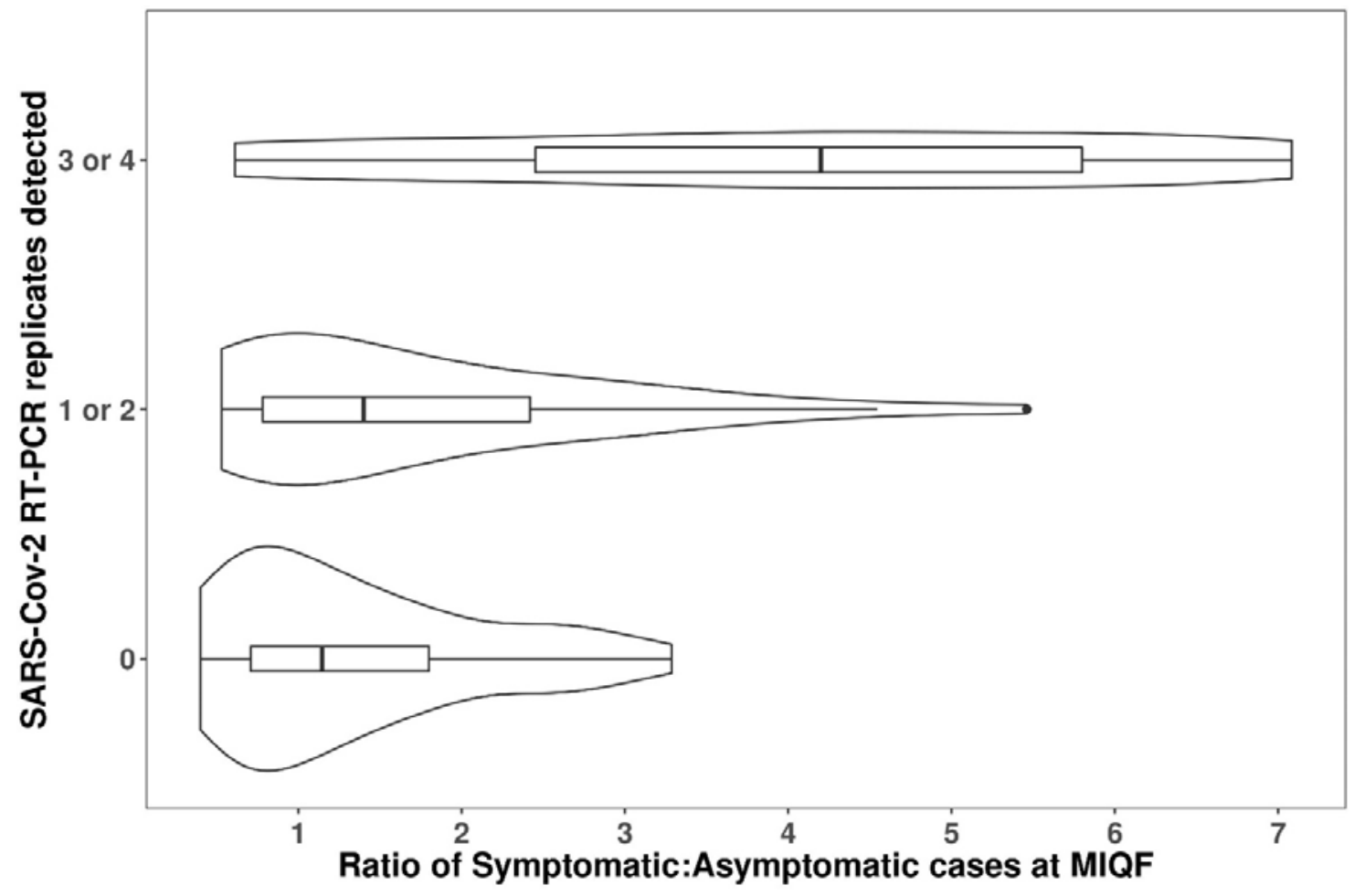

453 Fig. 6. The proportion of symptomatic cases to asymptomatic cases (model 1) at the MIQF 454 by the number of RT-qPCR replicates positive for SARS-CoV-2 RNA at the WWTP.

4. Discussion

457 In this study, by comparing actual case counts with models estimating number of infectious

458 individuals, we have shown that SARS-CoV-2 RNA can be detected in wastewater when 459 relatively few infectious individuals are contributing to the sample. For example, detection 460 probability was $87 \%$ when the infectious case prevalence (model 3) was $0.01 \%$ (i.e,.10 461 infectious cases per 100,000 population). While SARS-CoV-2 RNA can be detected when 462 there is only one infectious case in 100,000 population, the predicted probability was lower at $46329 \%$. Hence, in communities with very low numbers of COVID-19 cases, false negative 464 results may occur. This false negative result may occur at the sample scale, because the 
medRxiv preprint doi: https://doi.org/10.1101/2021.08.24.21258577; this version posted August 26, 2021. The copyright holder for this preprint (which was not certified by peer review) is the author/funder, who has granted medRxiv a license to display the preprint in perpetuity.

All rights reserved. No reuse allowed without permission.

465 amount of viral RNA within the sample is below the limit of detection. Alternatively, the 466 sample could be a true negative (i.e., no SARS-CoV-2 RNA is present in the sample) but be a

467 false negative at the community scale because the sample collected did not capture the 468 intermittent and low levels of SARS-CoV-2 RNA in the wastewater system. Even if sampling 469 could somehow test all the wastewater in a community, shedding from infectious individuals 470 whose residence is served by a septic tank or who are otherwise not connected to the 471 wastewater system will also not be detected. These factors must be considered when 472 interpreting and communicating results to public health authorities.

\section{WBE sensitivity estimates}

474 Previous estimates of the sensitivity of SARS-CoV-2 RNA detection in wastewater have 475 varied widely and few have considered the effect that variable shedding patterns over the 476 course of an infection will have on estimates. Hart et al. (2020) suggest that, depending on 477 local conditions, a single COVID-19 case would be theoretically detectable using WBE from 478 a catchment of 100 (1\% infection rate, least sensitive) to 2,000,000 (0.00005\% infection rate, 479 most sensitive) people, based on excretion rates, wastewater flow rates and detection limit of $48010 \mathrm{GC} / \mathrm{mL}$ (i.e., $10^{4} \mathrm{GC} / \mathrm{L}$ ) wastewater. Our data tested these estimates and found that 481 detection with $0.00005 \%$ prevalence would be highly unlikely, whereas detection with a $1 \%$ 482 prevalence would be highly likely. Indeed, detection with prevalence of $0.005 \%$ was possible, 483 but was more reliable $(90-100 \%)$ at a $0.03 \%$ or higher prevalence (i.e., 30 total cases in 484100,000 population). The sensitivity reported in our study is similar to that reported by Hata 485 et al. (2021) who concluded that, while there was a possibility that SARS-CoV-2 RNA could 486 be detected in wastewater when the number of cases was less than 1 per 100,000 (0.001\%), 487 detections were more likely when COVID-19 cases exceeded 10 per 100,000 population 488 (0.01\%). Medema et al. (2020b) reported somewhat higher sensitivity, with positive 
medRxiv preprint doi: https://doi.org/10.1101/2021.08.24.21258577; this version posted August 26, 2021. The copyright holder for this preprint (which was not certified by peer review) is the author/funder, who has granted medRxiv a license to display the preprint in perpetuity.

All rights reserved. No reuse allowed without permission.

4905 cases per 100,000 population (0.005\%) (Table 3). Other studies (e.g., Baldovin et al. 2021,

491 Hong et al. 2021) have reported lower sensitivity. Differences in sensitivity between studies

492 may be caused by variation in number of asymptomatic and pre-symptomatic individuals, and

493 COVID-19 testing rates, in different localities. As the number of undetected COVID-19 cases

494 contributing to wastewater increases, precision of sensitivity estimates reduces. Most

495 previous studies were based on reported cases, which are assumed to underrepresent actual

496 infections in communities with widespread community transmission.

\section{Use of shedding models}

498 The amount of shedding by individuals is known to vary person to person, and over time

499 (Hoffmann and Alsing 2021). In this study, some individuals stayed at the MIQF for over 30

500 days (average 13 days), during which time the amount of SARS-CoV-2 RNA shed via faeces

501 and respiratory excretions likely varied from high to undetectable levels Using total COVID-

50219 cases as an indicator of SARS-CoV-2 RNA shedding per person provides a conservative

503 estimate of the sensitivity of detecting SARS-CoV-2 RNA in wastewater. This is because

504 individuals towards the end of their infectious period, and potentially shedding at low levels,

505 are counted equally with people at the start of their infectious period. Both models 2 and 3

506 assumed that viral shedding was minimal nine days after illness onset (Cevik et al. 2021).

507 While SARS-CoV-2 RNA continues to be shed for prolonged periods in some individuals

508 (Gupta et al. 2020), which could have resulted in a sensitivity overestimate in our study, the

509 impact of this is likely to be minimal, as almost all cases left the MIQF (and most presumably

510 from the larger WWTP catchment) within 12 days of reported illness onset. Models 3 and 4

511 provided similar estimates of detection probability. This similarity likely reflects that

512 detection (and movement into MIQF) for most cases occurred in the early stages of their

513 infection. Unsurprisingly, the probability of SARS-CoV-2 RNA detection at the WWTP

514 increased as case numbers rose. This was evident during the period of community cases 
medRxiv preprint doi: https://doi.org/10.1101/2021.08.24.21258577; this version posted August 26, 2021. The copyright holder for this preprint (which was not certified by peer review) is the author/funder, who has granted medRxiv a license to display the preprint in perpetuity.

All rights reserved. No reuse allowed without permission.

515 within the study catchment, when SARS-CoV-2 RNA was detected with quantifiable

516 concentrations at the WWTP. Over the course of this study, the number of new daily cases

517 (model 4) ranged from 0 to 17 , with an average of two new cases per day. Using new daily

518 cases to estimate a positive detection of SARS-CoV-2 RNA therefore had little support

519 beyond 10 new daily cases due to the low case prevalence during the study period (Fig. 5c).

\section{Shedding by asymptomatic cases}

521 Our data suggest that symptomatic individuals may shed a higher amount of SARS-CoV-2

522 RNA into wastewater than asymptomatic individuals (Fig. 6). Wastewater testing is

523 potentially one of the best ways to detect asymptomatic cases in a community, as they are

524 otherwise unlikely to be tested unless they are close contacts of symptomatic cases. During

525 our study, asymptomatic case load was not significantly associated with increased SARS-

526 CoV-2 RNA detection in wastewater for any shedding models. It is possible that

527 asymptomatic cases in our study may have been tested longer after infection than

528 symptomatic cases, many of whom were tested immediately upon developing symptoms.

529 Studies specifically investigating differences in shedding between symptomatic and 530 asymptomatic individuals, particularly in faeces, would be valuable. We are aware of only a

531 few studies where SARS-CoV-2 RNA has been detected in the faeces of asymptomatic 532 individuals (e.g., Li et al. 2020, Yuan et al. 2021).

\section{$533 \quad$ Near-source tracking}

534 As part of this study, we have showed that at a building level, wastewater analysis has a very 535 high probability of detecting SARS-CoV-2 RNA shed from COVID-19 cases, even when 536 total infectious COVID-19 cases are few. This wastewater 'near-source tracking' has been 537 used to target surveillance where it is most needed (Medema et al. 2020a) such as in 538 university campuses and schools (Crowe et al. 2021), elderly care facilities and hospitals 539 (Davó et al. 2021, Spurbeck et al. 2021), and households (Döhla et al. 2020). Similar to the 
medRxiv preprint doi: https://doi.org/10.1101/2021.08.24.21258577; this version posted August 26, 2021. The copyright holder for this preprint (which was not certified by peer review) is the author/funder, who has granted medRxiv a license to display the preprint in perpetuity.

All rights reserved. No reuse allowed without permission.

540 concept of the MIQF used in our study, Hong et al. (2021) used a semi-controlled

541 community, namely a hospital with COVID-19 cases in Jeddah, Saudi Arabia, to examine the

542 detection sensitivity of WBE. They calculated sensitivity of ?253 positive cases per 10,000

543 population $(2.5 \%$ prevalence) for reliable detection in wastewater collected via a grab-

544 sample. Baldovin et al. (2021) sampled localised urban wastewater lines in Padua, Italy

545 during a time of high COVID-19 case numbers. The authors calculated a detection sensitivity

546 of 1 case per 531 hospitalised inhabitants ( $0.19 \%$ prevalence) for reliable detection.

\section{Sampling frequency}

548 Daily sampling, as undertaken in this study, provides the best understanding of potential viral

549 RNA shedding in the community and the earliest response opportunity. Based on our study, 550 detecting 0.8 to 4.2 cases in 100,000 is possible, although shedding dynamics, and

551 wastewater factors such as dilution and distance of cases from the sampling site, means that

552 the likelihood of detection in a single wastewater sample might only be $20-50 \%$. As daily

553 testing may not be practical, investigations around the optimal frequency of wastewater

554 sampling in a low prevalence setting would be a fruitful area of research.

\section{Conclusions}

556 By quantifying the detection limit of SARS-CoV-2 RNA in wastewater where the number of

557 contributing symptomatic and asymptomatic COVID-19 cases was known, and through

558 modelling viral RNA shedding, this study demonstrates that even with very low numbers of

559 infected individuals in a WWTP catchment there is a high probability (>90\% depending on

560 shedding assumption model) of detecting SARS-CoV-2 RNA in wastewater. As such,

561 wastewater can be used as both an early warning system of community outbreaks and for

562 longer term surveillance. However, it is important to carefully consider how cases are

563 quantified/modelled, and the relative contributions of symptomatic and asymptomatic 
medRxiv preprint doi: https://doi.org/10.1101/2021.08.24.21258577; this version posted August 26, 2021. The copyright holder for this preprint (which was not certified by peer review) is the author/funder, who has granted medRxiv a license to display the preprint in perpetuity.

All rights reserved. No reuse allowed without permission.

564 individuals when estimating sensitivity and interpreting results of WBE studies of SARS-

565 CoV-2.

566 Funding information

567 This work was supported by the Ministry of Business and Innovation COVID-19 Innovation

568 Acceleration Fund, grant number CIAF-0840. The funders had no role in study design;

569 collection, analysis, and interpretation of data; manuscript writing or the submission process.

\section{Acknowledgements}

571 The authors would like to thank residents and staff at the MIQF and WWTP catchment for

572 their wastewater inputs, and staff who collected samples and helped with logistics. Carmen

573 Vettori, Donna Marie Warren and Mary Brunsdon (ESR) assisted with sample accessioning

574 and laboratory support services, Alex Eustace, Amy Bradshaw and Tammy Waters (ESR)

575 helped with sample processing and/or analysis, Beverly Horn and Jenny Ralston (ESR)

576 provided assistance with statistical analysis and graphics respectively. Magda Dunowska

577 (Massey University, New Zealand) provided the feline infectious peritonitis virus (FIPV),

578 ATCC VR-990 strain WSU 79-1146 and designed the primers. Pradip Gyawali (ESR)

579 designed the FIPV probe. Murine norovirus was kindly provided by Prof Herbert Virgin

580 (Washington University School of Medicine, MO, US). Watershed Engineering Ltd

581 conducted mapping of the sewershed and developed estimates of resident population. Liza

582 Lopez (ESR) extracted case data from EpiSurv - a secure web-based application based on the

583 Surveillance Information New Zealand (SurvINZ) architecture. The authors thank the team

584 that maintain EpiSurv and those who have uploaded case data. We also appreciate comments

585 on an earlier version from Erasmus Smit, Gerard Sonder and Phil Carter (ESR). 
586 Supplementary Table S1. Primers and probes used for this study.

\begin{tabular}{llll}
\hline Target & Name & Sequence $\mathbf{( 5 ' - 3 ' )}$ & Reference \\
\hline SARS-CoV-2 N-gene & N-gene forward & GGGGAACTTCTCCTGCTAGAAT & (Chinese Center for Disease \\
& N-gene reverse & CAGACATTTTGCTCTCAAGCTG & Control and Prevention 2020) \\
& N-gene probe & FAM-TTGCTGCTGCTTGACAGATT-BHQ1 & (Dunowska and Ghosh 2021) \\
Feline infectious & FIPV forward & GCACGTACTGACAATTTGAGTGAACA & This Study \\
peritonitis virus (FIPV) & FIPV reverse & TCTCCCCAGTTGACGCGTTGT & (Hewitt et al. 2009) \\
& FIPV probe & FAM-ACTAAACTTTCAAATGGCCACACAGGG-BHQ1 & \\
Murine norovirus (MNV) & MNV forward & TGCAAGCTCTACAACGAAGG & \\
& MNV reverse & CACAGAGGCCAATTGGTAAA & \\
\hline
\end{tabular}


587 Supplementary Table S2. Logistic regression model parameter estimates for the probability

588 of detecting SARS-CoV-2 RNA in wastewater. Table S2A describes the logistic regression

589 models excluding the community cluster period. Table S2B describes the logistic regression

590 models including the community cluster period. Table S2C describes the logistic regression

591 models where symptomatic cases and asymptomatic cases are considered separately. Df is

592 degrees of freedom

\begin{tabular}{|c|c|c|c|c|}
\hline & Model & Explanatory variable & Coefficient estimate & p value \\
\hline \multirow[t]{12}{*}{ A } & \multicolumn{4}{|c|}{$\begin{array}{l}\text { Excluding community cases, } \mathbf{d f}=\mathbf{6 7} \\
\text { MIQF occupancy (model 1) }\end{array}$} \\
\hline & & Intercept & -1.72 & $0.012 *$ \\
\hline & & Shedding level & 0.07 & $0.018 *$ \\
\hline & \multicolumn{4}{|c|}{ Infectious cases (model 2) } \\
\hline & & Intercept & -1.54 & $0.022 *$ \\
\hline & & Shedding level & 0.12 & $0.033 *$ \\
\hline & \multicolumn{4}{|c|}{ Relative infectious cases (model 3) } \\
\hline & & Intercept & -1.21 & 0.068 \\
\hline & & Shedding level & 0.31 & 0.113 \\
\hline & \multicolumn{4}{|c|}{ New daily cases (model 4) } \\
\hline & & Intercept & -0.47 & 0.192 \\
\hline & & Shedding level & 0.13 & 0.372 \\
\hline \multirow[t]{12}{*}{ B } & \multicolumn{4}{|c|}{ Including community cases, $\mathrm{df}=112$} \\
\hline & & Intercept & -1.23 & $<0.001 *$ \\
\hline & & Shedding level & 0.05 & $<0.001 *$ \\
\hline & \multicolumn{4}{|c|}{ Infectious cases (model 2) } \\
\hline & & Intercept & -1.48 & $<0.001 *$ \\
\hline & & Shedding level & 0.09 & $<0.001 *$ \\
\hline & \multicolumn{4}{|c|}{ Relative infectious cases (model 3) } \\
\hline & & Intercept & -1.13 & $0.003 *$ \\
\hline & & Shedding level & 0.24 & $<0.001 *$ \\
\hline & \multicolumn{4}{|c|}{ New daily cases (model 4) } \\
\hline & & Intercept & -0.47 & 0.090 \\
\hline & & Shedding level & 0.25 & $0.003 *$ \\
\hline
\end{tabular}

C Separate terms for symptomatic and asymptomatic cases, $\mathrm{df}=112$ MIQF occupancy (model 1)

$-0.98 \quad 0.008 *$

Symptomatic shedding level $\quad 0.05 \quad 0.003^{*}$

Infectious cases (model 2)

Asymptomatic shedding level $\quad 0.01 \quad 0.681$

Intercept $\quad-1.33 \quad 0.002 *$

Symptomatic shedding level $\quad 0.13 \quad 0.002 *$

Infectious cases (model 3)

Asymptomatic shedding level $\quad 0.04 \quad 0.488$

$\begin{array}{lcc}\text { Intercept } & -1.06 & 0.010^{*} \\ \text { Symptomatic shedding level } & 0.04 & 0.002^{*}\end{array}$


medRxiv preprint doi: https://doi.org/10.1101/2021.08.24.21258577; this version posted August 26, 2021. The copyright holder for this preprint (which was not certified by peer review) is the author/funder, who has granted medRxiv a license to display the preprint in perpetuity.

All rights reserved. No reuse allowed without permission.

Asymptomatic
New daily cases (model 4)

Intercept

Symptomatic shedding level

Asymptomatic shedding level
0.06

$-0.44$

0.33

0.12
0.661

0.113

$0.008 *$

0.461

* statistically significant result $(\mathrm{p}<0.05)$

593 
medRxiv preprint doi: https://doi.org/10.1101/2021.08.24.21258577; this version posted August 26, 2021. The copyright holder for this preprint (which was not certified by peer review) is the author/funder, who has granted medRxiv a license to display the preprint in perpetuity.

All rights reserved. No reuse allowed without permission.

594 Supplementary Figure S1. Distribution process control recovery rates. Feline infectious

595 peritonitis virus (FIPV) and murine norovirus (MNV) recovery, from MIQF (red) and

596 WWTP (blue) samples using A) $200 \mu \mathrm{L}$ extraction volume; B) $50 \mu \mathrm{L}$ extraction volume is

597 shown. Note that $50 \mu \mathrm{L}$ extractions were not performed for all samples hence fewer

598 datapoints.

599
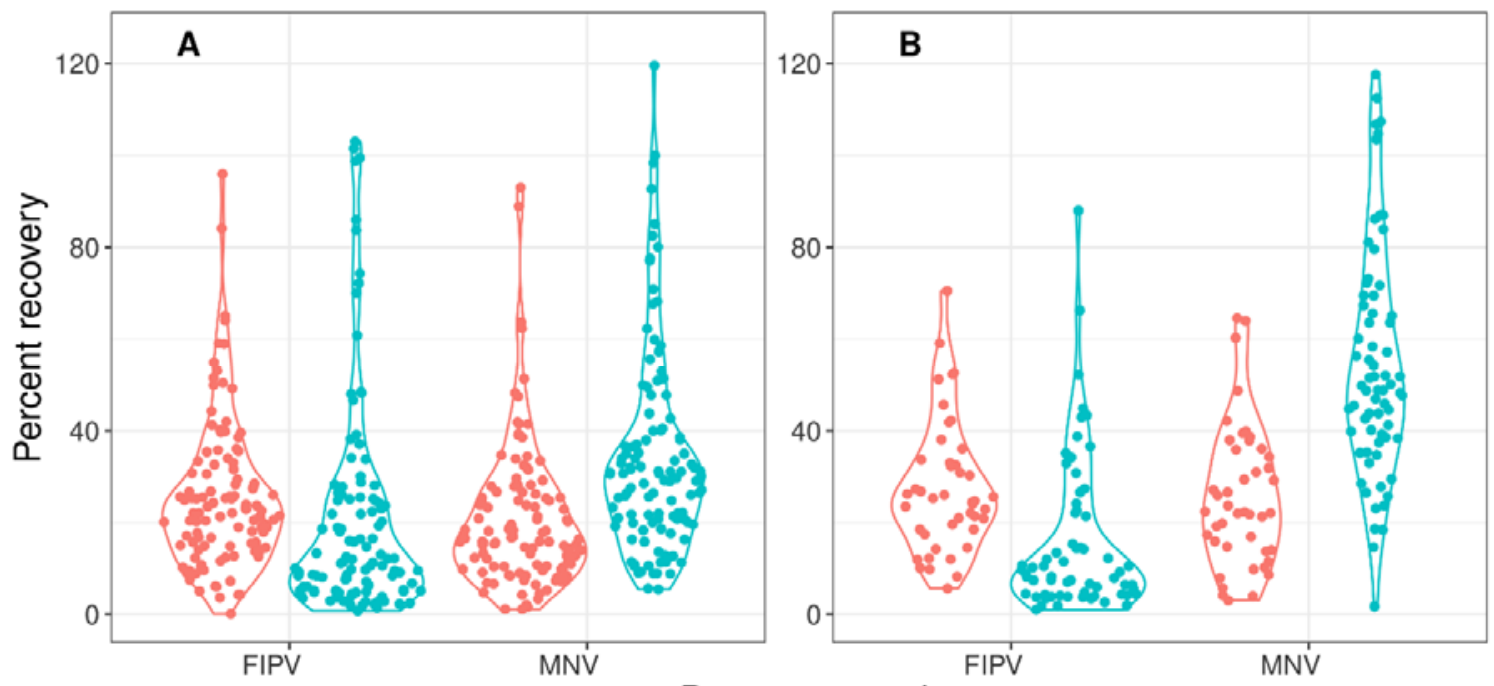

Site

- MIQ

600 Supplementary Table S3. Bootstrap 95\% confidence intervals for recovery of the process

601 controls, feline infectious peritonitis virus (FIPV) and murine norovirus (MNV), from MIQF

602 and WWTP samples using $200 \mu \mathrm{L}$ extraction volume; $50 \mu \mathrm{L}$ extraction volume. Note that 50

$603 \mu \mathrm{L}$ extractions were not performed for all samples, hence fewer datapoints. Bootstrap

604 confidence intervals were estimated from 10000 bootstrap samples.

\begin{tabular}{ccccccc}
\hline $\begin{array}{c}\text { Volume } \\
\text { extracted }\end{array}$ & Location & $\begin{array}{c}\text { Number of } \\
\text { samples }\end{array}$ & $\begin{array}{c}\text { Process } \\
\text { control }\end{array}$ & Mean & 95\% Confidence interval \\
\hline \multirow{5}{*}{$200 \mu \mathrm{L}$} & MIQF & 113 & FIPV & $25.4 \%$ & 22.5 & 28.4 \\
& MIQF & 113 & MNV & $20.9 \%$ & 18.2 & 23.9 \\
& WWTP & 113 & FIPV & $20.8 \%$ & 15.6 & 25.2 \\
& WWTP & 113 & MNV & $34.0 \%$ & 30.0 & 38.3 \\
\cline { 6 - 7 } $50 \mu \mathrm{L}$ & MIQF & 44 & FIPV & $27.7 \%$ & 23.7 & 32.1 \\
& MIQF & 44 & MNV & $25.8 \%$ & 23.1 & 32.3 \\
& WWTP & 65 & FIPV & $17.7 \%$ & 12.9 & 23.5 \\
& WWTP & 70 & MNV & $54.7 \%$ & 49.5 & 61.7 \\
\hline
\end{tabular}


medRxiv preprint doi: https://doi.org/10.1101/2021.08.24.21258577; this version posted August 26, 2021. The copyright holder for this preprint (which was not certified by peer review) is the author/funder, who has granted medRxiv a license to display the preprint in perpetuity.

All rights reserved. No reuse allowed without permission.

\section{References}

608 AJMC Staff. (2021) A Timeline of COVID-19 Developments in 2020.

609 https://www.ajmc.com/view/a-timeline-of-covid19-developments-in-2020. Accessed on 30 March 2021.

611 Baker, M.G., Wilson, N. and Anglemyer, A. (2020) Successful elimination of Covid-19

612 transmission in New Zealand. New England Journal of Medicine 383(8), e56.

613 Baldovin, T., Amoruso, I., Fonzo, M., Buja, A., Baldo, V., Cocchio, S. and Bertoncello, C.

614 (2021) SARS-CoV-2 RNA detection and persistence in wastewater samples: An experimental network for COVID-19 environmental surveillance in Padua, Veneto Region (NE Italy). Science of the Total Environment 760, 143329.

617 Betancourt, W.Q., Schmitz, B.W., Innes, G.K., Prasek, S.M., Pogreba Brown, K.M., Stark, 618 E.R., Foster, A.R., Sprissler, R.S., Harris, D.T., Sherchan, S.P., Gerba, C.P. and Pepper, 619 I.L. (2021) COVID-19 containment on a college campus via wastewater-based epidemiology, targeted clinical testing and an intervention. Science of The Total Environment 779, 146408.

Bivins, A., North, D., Ahmad, A., Ahmed, W., Alm, E., Been, F., Bhattacharya, P., Bijlsma, L., Boehm, A.B., Brown, J., Buttiglieri, G., Calabro, V., Carducci, A., Castiglioni, S., 
medRxiv preprint doi: https://doi.org/10.1101/2021.08.24.21258577; this version posted August 26, 2021. The copyright holder for this preprint (which was not certified by peer review) is the author/funder, who has granted medRxiv a license to display the preprint in perpetuity.

All rights reserved. No reuse allowed without permission.

632

633

634

635

636

637

638

639

640

641

642

643

644

645

646

647

648

649

650

651

652

653

654

655

maximize contributions in the fight against COVID-19. Environmental Science and Technology 54(13), 7754-7757.

Canales, R.A., Wilson, A.M., Pearce-Walker, J.I., Verhougstraete, M.P. and Reynolds, K.A. (2018) Methods for handling left-censored data in quantitative microbial risk assessment. Applied and Environmental Microbiology 84(20).

Cao, B., Gu, A.Z., Hong, P.-Y., Ivanek, R., Li, B., Wang, A. and Wu, J. (2020) Editorial perspective: Viruses in wastewater: Wading into the knowns and unknowns. Environmental Research, 110255.

Cevik, M., Tate, M., Lloyd, O., Maraolo, A.E., Schafers, J. and Ho, A. (2021) SARS-CoV-2, SARS-CoV, and MERS-CoV viral load dynamics, duration of viral shedding, and infectiousness: a systematic review and meta-analysis. The Lancet Microbe 2(1), e13e22.

Chavarria-Miro, G., Anfruns-Estrada, E., Martinez-Velazquez, A., Vazquez-Portero, M., Guix, S., Paraira, M., Galofre, B., Sanchez, G., Pinto, R.M. and Bosch, A. (2021) Time evolution of Severe Acute Respiratory Syndrome Coronavirus 2 (SARS-CoV-2) in wastewater during the first pandemic wave of COVID-19 in the metropolitan area of Barcelona, Spain. Applied and Environmental Microbiology 87(7).

Chinese Center for Disease Control and Prevention (2020) Technical guidelines for COVID19 laboratory testing. China CDC Weekly 2(19), 332-336.

Crowe, J., Schnaubelt, A.T., Schmidt-Bonne, S., Angell, K., Bai, J., Eske, T., Nicklin, M., Pratt, C., White, B., Crotts-Hannibal, B., Staffend, N., Herrera, V., Cobb, J., Conner, J., Carstens, J., Tempero, J., Bouda, L., Ray, M., Lawler, J.V., Campbell, W.S., Lowe, J.M., Santarpia, J., Bartelt-Hunt, S., Wiley, M., Brett-Major, D., Logan, C. and Broadhurst, M.J. (2021) Pilot program for test-based SARS-CoV-2 screening and 
medRxiv preprint doi: https://doi.org/10.1101/2021.08.24.21258577; this version posted August 26, 2021. The copyright holder for this preprint (which was not certified by peer review) is the author/funder, who has granted medRxiv a license to display the preprint in perpetuity.

All rights reserved. No reuse allowed without permission.

656

657

658

659

660

661

662

663

664

665

666

667

668

669

670

671

672

673

674

675

676

677

678

679

680

environmental monitoring in an urban public school district. medRxiv, 2021.2004.2014.21255036.

Davó, L., Seguí, R., Botija, P., Beltrán, M.J., Albert, E., Torres, I., López-Fernández, P.Á., Ortí, R., Maestre, J.F., Sánchez, G. and Navarro, D. (2021) Early detection of SARSCoV-2 infection cases or outbreaks at nursing homes by targeted wastewater tracking. Clinical Microbiology and Infection, S1198-1743X(1121)00078-00071.

Döhla, M., Wilbring, G., Schulte, B., Kümmerer, B.M., Diegmann, C., Sib, E., Richter, E., Haag, A., Engelhart, S., Eis-Hübinger, A.M., Exner, M., Streeck, H. and Schmithausen, R.M. (2020) SARS-CoV-2 in environmental samples of quarantined households. medRxiv, 2020.2005.2028.20114041.

Dunowska, M. and Ghosh, S. (2021) In vitro effects of doxycycline on replication of feline coronavirus. Pathogens 10(3).

Foladori, P., Cutrupi, F., Segata, N., Manara, S., Pinto, F., Malpei, F., Bruni, L. and La Rosa, G. (2020) SARS-CoV-2 from faeces to wastewater treatment: What do we know? A review. Science of The Total Environment 743, 140444.

Gibas, C., Lambirth, K., Mittal, N., Juel, M.A.I., Barua, V.B., Brazell, L.R., Hinton, K., Lontai, J., Stark, N., Young, I., Quach, C., Russ, M., Kauer, J., Nicolosi, B., Akella, S., Tang, W., Chen, D., Schlueter, J. and Munir, M. (2021) Implementing building-level SARS-CoV-2 wastewater surveillance on a university campus. Science of the Total Environment 782, 146749.

Gupta, S., Parker, J., Smits, S., Underwood, J. and Dolwani, S. (2020) Persistent viral shedding of SARS-CoV-2 in faeces - a rapid review. Colorectal Disease 22(6), 611620.

Harris-Lovett, S., Nelson, K.L., Beamer, P., Bischel, H.N., Bivins, A., Bruder, A., Butler, C., Camenisch, T.D., Long, S.K.D., Karthikeyan, S., Larsen, D.A., Meierdiercks, K., 
medRxiv preprint doi: https://doi.org/10.1101/2021.08.24.21258577; this version posted August 26, 2021. The copyright holder for this preprint (which was not certified by peer review) is the author/funder, who has granted medRxiv a license to display the preprint in perpetuity.

All rights reserved. No reuse allowed without permission.

681

682

683

684

685

686

687

688

689

690

691

692

693

694

695

696

697

698

699

700

701

702

703

704

705

Mouser, P.J., Pagsuyoin, S., Prasek, S.M., Radniecki, T.S., Ram, J.L., Roper, D.K., Safford, H., Sherchan, S.P., Shuster, W., Stalder, T., Wheeler, R.T. and Korfmacher, K.S. (2021) Wastewater surveillance for SARS-CoV-2 on college campuses: Initial efforts, lessons learned and research needs. International Journal of Environmental Research and Public Health 18(9), 4455.

Hart, O.E. and Halden, R.U. (2020) Computational analysis of SARS-CoV-2/COVID-19 surveillance by wastewater-based epidemiology locally and globally: Feasibility, economy, opportunities and challenges. Science of the Total Environment 730, 138875.

Hata, A., Hara-Yamamura, H., Meuchi, Y., Imai, S. and Honda, R. (2021) Detection of SARS-CoV-2 in wastewater in Japan during a COVID-19 outbreak. Science of the Total Environment 758, 143578.

He, X., Lau, E.H.Y., Wu, P., Deng, X.L., Wang, J., Hao, X.X., Lau, Y.C., Wong, J.S.Y., Guan, Y.J., Tan, X.H., Mo, X.N., Chen, Y.Q., Liao, B.L., Chen, W.L., Hu, F.Y., Zhang, Q., Zhong, M.Q., Wu, Y.R., Zhao, L.Z., Zhang, F.C., Cowling, B.J., Li, F. and Leung, G.M. (2020) Temporal dynamics in viral shedding and transmissibility of COVID-19. Nature Medicine 26(5).

Hewitt, J., Rivera-Aban, M. and Greening, G.E. (2009) Evaluation of murine norovirus as a surrogate for human norovirus and hepatitis A virus in heat inactivation studies. Journal of Applied Microbiology 107(1), 65-71.

Hoffmann, T. and Alsing, J. (2021) Faecal shedding models for SARS-CoV-2 RNA amongst hospitalised patients and implications for wastewater-based epidemiology. medRxiv, 2021.2003.2016.21253603.

Hong, P.Y., Rachmadi, A.T., Mantilla-Calderon, D., Alkahtani, M., Bashawri, Y.M., Al Qarni, H., O'Reilly, K.M. and Zhou, J. (2021) Estimating the minimum number of SARS-CoV-2 infected cases needed to detect viral RNA in wastewater: To what extent 
medRxiv preprint doi: https://doi.org/10.1101/2021.08.24.21258577; this version posted August 26, 2021. The copyright holder for this preprint (which was not certified by peer review) is the author/funder, who has granted medRxiv a license to display the preprint in perpetuity.

All rights reserved. No reuse allowed without permission.

706

707

708

709

710

711

712

713

714

715

716

717

718

719

720

721

722

723

724

725

726

727

728

of the outbreak can surveillance of wastewater tell us? Environmental Research 195, 110748.

Jefferies, S., French, N., Gilkison, C., Graham, G., Hope, V., Marshall, J., McElnay, C., McNeill, A., Muellner, P., Paine, S., Prasad, N., Scott, J., Sherwood, J., Yang, L. and Priest, P. (2020) COVID-19 in New Zealand and the impact of the national response: a descriptive epidemiological study. Lancet Public Health 5(11), E612-E623.

Kantor, R.S., Nelson, K.L., Greenwald, H.D. and Kennedy, L.C. (2021) Challenges in measuring the recovery of SARS-CoV-2 from wastewater. Environmental Science and Technology 55(6), 3514-3519.

Li, W., Su, Y.Y., Zhi, S.S., Huang, J., Zhuang, C.L., Bai, W.Z., Wan, Y., Meng, X.R., Zhang, L., Zhou, Y.B., Luo, Y.Y., Ge, S.X., Chen, Y.K. and Ma, Y. (2020) Virus shedding dynamics in asymptomatic and mildly symptomatic patients infected with SARS-CoV2. Clinical Microbiology and Infection 26(11).

Lodder, W. and Husman, A.M.D. (2020) SARS-CoV-2 in wastewater: potential health risk, but also data source. Lancet Gastroenterology and Hepatology 5(6), 533-534.

Medema, G., Been, F., Heijnen, L. and Petterson, S. (2020a) Implementation of environmental surveillance for SARS-CoV-2 virus to support public health decisions: Opportunities and challenges. Current Opinion in Environmental Science and Health $17,49-71$.

Medema, G., Heijnen, L., Elsinga, G., Italiaander, R. and Brouwer, A. (2020b) Presence of SARS-Coronavirus-2 RNA in sewage and correlation with reported COVID-19 prevalence in the early stage of the epidemic in The Netherlands. Environmental Science and Technology Letters 7(7), 511-516. 
medRxiv preprint doi: https://doi.org/10.1101/2021.08.24.21258577; this version posted August 26, 2021. The copyright holder for this preprint (which was not certified by peer review) is the author/funder, who has granted medRxiv a license to display the preprint in perpetuity.

All rights reserved. No reuse allowed without permission.

729 New Zealand Government. (2021) Welcome pack: Managed isolation facility for returnees to

$730 \quad$ New Zealand. https://www.miq.govt.nz/being-in-managed-isolation/entering-

731 isolation/welcome-pack/welcome-pack/. Accessed on 11 January 2021.

732 Peccia, J., Zulli, A., Brackney, D.E., Grubaugh, N.D., Kaplan, E.H., Casanovas-Massana, A.,

733 Ko, A.I., Malik, A.A., Wang, D., Wang, M.K., Warren, J.L., Weinberger, D.M.,

734 Arnold, W. and Omer, S.B. (2020) Measurement of SARS-CoV-2 RNA in wastewater

735 tracks community infection dynamics. Nature Biotechnology 38(10), 1164-+.

736 Pecson, B.M., Darby, E., Haas, C.N., Amha, Y., Bartolo, M., Danielson, R., Dearborn, Y., Di

737 Giovanni, G., Ferguson, C., Fevig, S., Gaddis, E., Gray, D., Lukasik, G., Mull, B.,

738 Olivas, L., Olivieri, A., Qu, Y. and Consortium, S.-C.-I. (2021) Reproducibility and

739 sensitivity of 36 methods to quantify the SARS-CoV-2 genetic signal in raw

740 wastewater: findings from an interlaboratory methods evaluation in the U.S.

741 Environmental Science: Water Research and Technology 7, 504-520.

742 R Core Team (2020) R: A Language and Environment for Statistical Computing, R

$743 \quad$ Foundation for Statistical Computing, Vienna, Austria.

744 Randazzo, W., Truchado, P., Cuevas-Ferrando, E., Simón, P., Allende, A. and Sánchez, G.

745 (2020) SARS-CoV-2 RNA in wastewater anticipated COVID-19 occurrence in a low

$746 \quad$ prevalence area. Water Research 181, 115942.

747 Sims, N. and Kasprzyk-Hordern, B. (2020) Future perspectives of wastewater-based

748 epidemiology: Monitoring infectious disease spread and resistance to the community

749 level. Environment International 139, 105689.

750 Spurbeck, R.R., Minard-Smith, A.T. and Catlin, L.A. (2021) Applicability of neighborhood

751 and building scale wastewater-based genomic epidemiology to track the SARS-CoV-2

752 pandemic and other pathogens. medRxiv, 2021.2002.2018.21251939. 
medRxiv preprint doi: https://doi.org/10.1101/2021.08.24.21258577; this version posted August 26, 2021. The copyright holder for this preprint (which was not certified by peer review) is the author/funder, who has granted medRxiv a license to display the preprint in perpetuity.

All rights reserved. No reuse allowed without permission.

753 Thompson, J.R., Nancharaiah, Y.V., Gu, X.Q., Lee, W.L., Rajal, V.B., Haines, M.B.,

754 Girones, R., Ng, L.C., Alm, E.J. and Wuertz, S. (2020) Making waves: Wastewater

755 surveillance of SARS-CoV-2 for population-based health management. Water Research

$756 \quad 184,116181$.

757 Walsh, K.A., Jordan, K., Clyne, B., Rohde, D., Drummond, L., Byrne, P., Ahern, S., Carty,

758 P.G., O'Brien, K.K., O'Murchu, E., O'Neill, M., Smith, S.M., Ryan, M. and Harrington,

759

760 P. (2020) SARS-CoV-2 detection, viral load and infectivity over the course of an

761

Wölfel, R., Corman, V.M., Guggemos, W., Seilmaier, M., Zange, S., Muller, M.A.,

762

763

764

765 Niemeyer, D., Jones, T.C., Vollmar, P., Rothe, C., Hoelscher, M., Bleicker, T.,

766

World Health Organisation. (2020) WHO Director-General's opening remarks at the media

767 briefing on COVID-19 - 11 March 2020. https://www.who.int/directorgeneral/speeches/detail/who-director-general-s-opening-remarks-at-the-media-briefingon-covid-19---11-march-2020. Accessed on 11 January 2021.

Wu, F.Q., Zhang, J.B., Xiao, A., Gu, X.Q., Lee, W.L., Armas, F., Kauffman, K., Hanage, W., Matus, M., Ghaeli, N., Endo, N., Duvallet, C., Poyet, M., Moniz, K., Washburne, A.D., Erickson, T., Chai, P., Thompson, J. and Alm, E. (2020) SARS-CoV-2 titers in

774 Yuan, C., Wang, H., Li, K., Tang, A., Dai, Y., Wu, B., Zhang, H., Chen, J., Liu, J., Wu, W., 775 Gu, S., Wang, H., Xu, H., Wu, M., Yu, M., Wang, Y., Yu, X., He, J., Liu, S., Zhang, 776 Y., Tong, Z. and Yan, J. (2021) SARS-CoV-2 viral shedding characteristics and 
medRxiv preprint doi: https://doi.org/10.1101/2021.08.24.21258577; this version posted August 26, 2021. The copyright holder for this preprint (which was not certified by peer review) is the author/funder, who has granted medRxiv a license to display the preprint in perpetuity.

All rights reserved. No reuse allowed without permission.

777 potential evidence for the priority for faecal specimen testing in diagnosis. PLoS One

$778 \quad 16(2), \mathrm{e} 0247367$.

779 Zhang, W., Du, R.H., Li, B., Zheng, X.S., Yang, X.L., Hu, B., Wang, Y.Y., Xiao, G.F., Yan,

780 B., Shi, Z.L. and Zhou, P. (2020) Molecular and serological investigation of 2019-

$781 \mathrm{nCoV}$ infected patients: implication of multiple shedding routes. Emerging Microbes

$782 \quad$ and Infections 9(1), 386-389.

783 